\title{
Influence of Sulphate Nutrition on Growth Performance and Antioxidant Enzymes Activities of Spirulina platensis
}

\author{
Pierre Fils Rodrigue Magwell ${ }^{1,3}$, Emile Minyaka ${ }^{1}$, Oscar Wamba Fotsop ${ }^{2}$, Marlyse Solange Leng ${ }^{1}$ \\ \& Léopold Gustave Lehman ${ }^{4}$ \\ ${ }^{1}$ Biochemistry Laboratory, Faculty of Science, University of Douala, Douala, Cameroon \\ ${ }^{2}$ Laboratory of Plant Biology, Faculty of Science, University of Douala, Douala, Cameroon \\ ${ }^{3}$ Institute of Agricultural Research for Development, Nko'olong Station, Kribi, Cameroon \\ ${ }^{4}$ Laboratory of Animal Biology and Physiology, Faculty of Science, University of Douala, Douala, Cameroon \\ Correspondence: Emile Minyaka, Biochemistry Laboratory, Faculty of Science, University of Douala, P.O. Box \\ 24157 Douala, Cameroon. Tel: 237-674-071-671. E-mail: minyakae@yahoo.fr
}

Received: December 8, 2020

Accepted: February 15, 2021

Online Published: September 15, 2021

doi:10.5539/jas.v13n10p115

URL: https://doi.org/10.5539/jas.v13n10p115

\begin{abstract}
The growth of Spirulina platensis is dependent on culture conditions. This study has established adequate conditions for the quality and quantity production of $S$. platensis. The effect of sulphate salts nutrition on growth performance and biochemical status of $S$. platensis was assessed in vitro. Prior to culture, the Paracas strain of $S$. platensis from SAGRIC pond was analysed in different magnesium sulphate $\left(\mathrm{MgSO}_{4} ; 0.08,0.16,0.32,0.64\right.$ and $1.28 \mathrm{~g} / \mathrm{L})$, potassium sulphate $\left(\mathrm{K}_{2} \mathrm{SO}_{4} ; 0.08,0.16,0.32,0.64\right.$ and $\left.1.28 \mathrm{~g} / \mathrm{L}\right)$ and $\mathrm{MgSO}_{4} / \mathrm{K}_{2} \mathrm{SO}_{4}(0.16 / 0.00$, $0.08 / 0.08,0.04 / 0.12,0.02 / 0.14$ and $0.01 / 0.15 \mathrm{~g} / \mathrm{L}$ ) concentrations. Culture media $\mathrm{pH}$, total dissolved solids (TDS) and conductivity rate were monitored. Microscopic analysis revealed sulphate salt concentrations influenced the number of whorls and filaments of $S$. platensis. $\mathrm{K}_{2} \mathrm{SO}_{4}(1.28 \mathrm{~g} / \mathrm{L})$ produced the highest number of whorls and filaments. Moreover, $\mathrm{pH}$ level fluctuated by sulphate treatments. $\mathrm{K}_{2} \mathrm{SO}_{4}(1.28 \mathrm{~g} / \mathrm{L})$ had a $\mathrm{pH}$ level of $8.77 \pm 0.01$ (day 5 of culture incubation). TDS and conductivity rate, protein and cysteine contents increased with culture age and $\mathrm{K}_{2} \mathrm{SO}_{4}$ concentration in a culture medium. Conversely, negative correlations between protein and cysteine contents were observed, and sugar content decreased. Sulphate salt type and concentrations affected polyphenol oxidase (PPO) and peroxidase (POD) activities. $\mathrm{MgSO}_{4} / \mathrm{K}_{2} \mathrm{SO}_{4}(0.02 / 0.14 \mathrm{~g} / \mathrm{L})$ displayed the best PPO and POD activities. Both enzymes appeared to be negatively correlated to the decreasing sugar content. These results indicate growth performances and biochemical status of $S$. platensis are significantly improved with the adequate supplementation of sulphate salts $\left(\mathrm{MgSO}_{4}\right.$ and $\left.\mathrm{K}_{2} \mathrm{SO}_{4}\right)$ in culture media.
\end{abstract}

Keywords: Spirulina platensis, sulphate salts, growth, antioxidant activity

\section{Introduction}

Spirulina platensis is a multicellular, filamentous and microscopic photosynthetic cyanobacterium commonly found in the brackish lakes of Central Africa and Mexico. S. platensis has been consumed for centuries by the Aztecs and bordering populations on Lake Chad (Shigekatsu et al., 2019). This microalgae is characterized by a high content of protein (including enzymes such as polyphenol oxidase and peroxidase) and high amounts of essential fatty acids, essential amino acids, minerals, vitamins (especially B12), polysaccharides and antioxidant pigments (chlorophyll, carotenoids, phycobiliprotein, phycocyanin and carotenoids) (Budiyono et al., 2014; Ben Amor et al., 2017; Jung et al., 2019; Fatemeh \& Choopani, 2020).

This microalgae is being studied, not only for its nutritional properties but also for its reported therapeutic properties related to its hypolipidemic effect (Al-Saman et al., 2020), protective effect against diabetes and obesity (Azabji-Kenfack et al., 2011; Gómez-Téllez et al., 2020), inhibitory effect on anemia and cancer (Abdel-Daim et al., 2013; Barakat et al., 2015), stimulatory effect on the immunological system (Ngo-Matip et al., 2015; Ama Moor et al., 2020), nephrotoxicity effect on pharmaceuticals and toxic metals and protective effect against harmful radiation (Mohan et al., 2006; Priyanka Yadav et al., 2019). Because of its multiple properties, the production of $S$. platensis has gained worldwide attention for use in human food supplements, animal feed and pharmaceuticals industries. 
In Cameroon, culture of spirulina remains rudimentary, not controlled by producers and its biochemical status uncertain. Biomass, specific growth and biochemical composition of spirulina depend on many factors which include farming practices, environmental parameters and culture medium composition (Madkour et al., 2012). However, composition of culture medium is a major factor which influences growth rate, biomass production and biochemical status of this cyanobacterium. Hence, it is possible to improve the growth performance, biochemical status and antioxidant activity of $S$. platensis while acting on composition of culture medium in order to fulfil pharmaceutical and nutritional requirements.

Therefore, the present study was undertaken to study the incidence of exogenous sulphate salts $\left(\mathrm{K}_{2} \mathrm{SO}_{4}\right.$ and $\mathrm{MgSO}_{4}$ ) supplementation on growth performance and biochemical profile (including antioxidant enzymes activities) of $S$. platensis cultured in vitro. Green algae growth is negatively influenced by harmful reactive oxygen species (ROS) from diver's physiological metabolic processes. Polyphenol oxidase and peroxidase are important antioxidant enzymes in stress control of the cell (Yakelín et al., 2001; Mostafa Mahmoud et al., 2016).

\section{Material and Methods}

\subsection{Microorganism Strain}

The cyanobacterium S. platensis strain «Paracas» used in the present study was obtained from the freshwater culture pond of SAGRIC Common Initiative Group (CIG) farm, Douala-Cameroon. The strain was grown and maintained in $500 \mathrm{~mL}$ sterilized Erlenmeyer flasks containing $100 \mathrm{~mL}$ Jourdan's medium (Table 1) (Jourdan, 2013) at $\mathrm{pH} 9$ in an illuminated growth room at $28 \pm 0.5{ }^{\circ} \mathrm{C}$ under $12 / 12$ hours photoperiod and daily manually shake (thrice).

\subsection{Culture Media and Experimental Design}

Jourdan's medium (Jourdan, 2013) was used as the reference medium. Sulphate salts $\left(\mathrm{MgSO}_{4}\right.$ and $\left.\mathrm{K}_{2} \mathrm{SO}_{4}\right)$ were brought in variable concentrations in Jourdan's medium. $\mathrm{MgSO}_{4}$ was varied in absence of $\mathrm{K}_{2} \mathrm{SO}_{4}$. Conversely, $\mathrm{K}_{2} \mathrm{SO}_{4}$ was varied in absence of $\mathrm{MgSO}_{4}$. Also, the ratios $\mathrm{MgSO}_{4} / \mathrm{K}_{2} \mathrm{SO}_{4}$ varied with fixed content of $\mathrm{SO}_{4}{ }^{2-}(\mathrm{Table}$ 1). The algae $S$. platensis cells were inoculated at a concentration of $15 \%$ (V inoculation/V media) in $1000 \mathrm{~mL}$ erlenmeyer flasks. The $\mathrm{pH}$ of all culture media was adjusted to 9 before sterilization, cool and addition of $S$. platensis cells $(15 \% \mathrm{v} / \mathrm{v})$. Cultures were incubated at 12/12 hours (light-darkness) photoperiod under temperature $28 \pm 0.5{ }^{\circ} \mathrm{C}$ for 5 days. Cultures were manually shook (for $3 \mathrm{~min}$ ) thrice daily. Samples were collected every day for assessment of the cyanobacteria growth as well as estimation of biochemical status and antioxidant enzymes activities. All experiments were carried out in triplicate.

Table 1. Composition of Jourdan's medium

\begin{tabular}{ll}
\hline Constituents & Composition $(\mathrm{g} / \mathrm{L})$ \\
\hline Urea $\left(\left(\mathrm{NH}_{2}\right)_{2} \mathrm{CO}\right)$ & 0.05 \\
Di-ammonium phosphate $\left(\left(\mathrm{NH}_{4}\right)_{2} \mathrm{HPO}_{4}\right)$ & 0.12 \\
Potassium nitrate $\left(\mathrm{KNO}_{3}\right)$ & 2 \\
Magnesium sulphate $\left(\mathrm{MgSO}_{4}\right)$ & 0.16 \\
Calcium chloride $\left(\mathrm{CaCl}_{2}\right)$ & 0.02 \\
Ferrous sulphate $(\mathrm{FeSO})$ & 0.02 \\
Sodium chloride $(\mathrm{NaCl})$ & 5 \\
Sodium bicarbonate $\left(\mathrm{NaHCO}_{3}\right)$ & 8 \\
\hline
\end{tabular}

\subsection{Monitoring of Physico-Chemical Parameters of Culture Media}

Physico-chemical parameters (temperature, $\mathrm{pH}$, conductivity, and total dissolved solids (TDS) of media were recorded daily using of multi-parameters (HI 98130, HANNA Instruments, Rhodes Island, USA).

\subsection{Assessment of S. platensis Growth Parameters}

S. platensis cell populations (number of filaments and whorls) were evaluated using light and fluorescence microscope (Cyscope ${ }^{\circledR}$ HP, Sysmex-Partec, Japan) by direct microscopic counting method described by Usharani et al. (2012). Biomass concentration $(\mathrm{g} / \mathrm{L}$ ) was determined every day by measuring the optical density at $560 \mathrm{~nm}$. A standard concentration was used to determine the biomass of individual samples (culture media and daily monitoring) based on optical density and use the coefficient of correlation $(\mathrm{C}=0.782 \mathrm{X}$, where $\mathrm{X}$ is the biomass concentration ( $\mathrm{g} / \mathrm{L}$ ) according to Tsarahevitra et al. (2003). The calculated biomass was used to obtain maximum specific growth rate $\left(\mu_{\mathrm{m}}\right)$ and productivity $(\mathrm{P})$ from the following equation of (Madkour et al., 2012): 


$$
\mu_{\mathrm{m}}=\ln \left(\mathrm{X}_{1} / \mathrm{X}_{2}\right) / \mathrm{t}_{2}-\mathrm{t}_{1}
$$

where, $\mu_{\mathrm{m}}=$ specific growth rate (div/day); $\mathrm{X}_{1}=$ biomass concentration at time $\mathrm{t}_{1} ; \mathrm{X}_{2}=$ biomass concentration at the time $t_{2}$.

Productivity $(\mathrm{P})$ was estimated as follow:

$$
\mathrm{P}=\left(\mathrm{X}_{\mathrm{m}}-\mathrm{X}_{\mathrm{i}}\right) / \mathrm{t}_{\mathrm{m}}
$$

where, $\mathrm{P}=$ productivity $(\mathrm{mg} / \mathrm{L} /$ day $) ; \mathrm{X}_{\mathrm{i}}=$ initial biomass density $(\mathrm{g} / \mathrm{L}) ; \mathrm{X}_{\mathrm{m}}=$ biomass density at time $\mathrm{m}(\mathrm{g} / \mathrm{L}) ; \mathrm{t}_{\mathrm{m}}$ = time interval (day) between $\mathrm{X}_{\mathrm{i}}$ and $\mathrm{X}_{\mathrm{m}}$.

\subsection{Chemical and Biochemical Analysis}

\subsubsection{Chemical Composition Analysis of S. platensis Strain Used}

The $S$. platensis sample from SAGRIC pond was aseptically filtered and dried during 48 hours at $50{ }^{\circ} \mathrm{C}$ in a sterilizer (Binder, Germany). Subsequently, the sample was analyzed to find out its chemical composition. Total protein was determined by the conventional Micro-Kjeldahl method (AOAC, 1995). Lipids were extracted using a Soxhlet apparatus and analyzed according to the AOAC (1990) method. Total ash and fibers were determined by the standards method of AOAC (1990) and Wolff (1968). The determination of minerals (Ca, Mg, K, Na, Fe and $\mathrm{P}$ ) was carried out using atomic absorption spectrophotometer after extraction in a mixture of nitrichydrochloric acid $(75 \mathrm{v} / 25 \mathrm{v})$.

\subsubsection{Biochemical Analysis of S. platensis in Experimental Design}

(1) Reducing Sugars and Cysteine Extraction and Analysis

Reducing sugars and cysteine were extracted in $80 \%$ ethanol. One $\mathrm{mL}$ of homogenized algal suspension was added in $5 \mathrm{~mL}$ of $80 \%$ ethanol in the mortar and then centrifuged (3000 $\mathrm{g}, 10 \mathrm{~min}$ ). The supernatant was collected and used for reducing sugars and cysteine contents quantification. Reducing sugars were assayed by mixing $0.1 \mathrm{~mL}$ of reducing sugars crude extract with $1.5 \mathrm{~mL}$ of water and $0.5 \mathrm{~mL}$ of Müller reagent [1\% (w/v) DNS (3,5-dinitro salicylic acid), $1.6 \% \mathrm{NaOH}(\mathrm{w} / \mathrm{v})$ and $30 \%(\mathrm{w} / \mathrm{v})$ sodium-potassium tartrate]. The mixture was homogenized and incubated at $100{ }^{\circ} \mathrm{C}$ for $10 \mathrm{~min}$ in the water bath to allow colour development. Optical density was measured at $575 \mathrm{~nm}$ using glucose as standard.

Cysteine content was estimated by the method describe by Gaitonde (1967). Cysteine crude extract $(0.15 \mathrm{~mL})$ was added to $0.35 \mathrm{~mL}$ of acidic ninhydrin reagent $\left[1,3 \%(\mathrm{w} / \mathrm{v})\right.$ Ninhydrine in 1:4 $\mathrm{HCl}: \mathrm{CH}_{3} \mathrm{COOH}$ conc]. The mixture was homogenized and heated at $100{ }^{\circ} \mathrm{C}$ for $10 \mathrm{~min}$ followed cooling in ice. A volume of $1 \mathrm{~mL}$ ethanol $95^{\circ}$ was added and the optical density read $560 \mathrm{~nm}$ against a blank where cysteine crude extract was replaced equal volumeof ethanol $80^{\circ}$.

\section{(2) Antioxidant Enzymes and Proteins Extraction}

Polyphenol oxidase and peroxidase were extracted by homogenizing $1 \mathrm{~g}$ of fresh $S$. platensis sample in a mortar containing $10 \mathrm{~mL}$ potassium phosphate buffer $(50 \mathrm{mM}, \mathrm{pH} 6.0)$. The homogenate was subsequently centrifuged $\left(6000 \mathrm{~g}, 30 \mathrm{~min}\right.$ at $\left.4^{\circ} \mathrm{C}\right)$ and the supernatant was collected. The pellet was re-suspended in the same buffer centrifuged under the same conditions as previously. The second supernatant was added to the first to obtain polyphenol oxidase and peroxidase preparation extract which was used for the analysis of proteins contents, polyphenol oxidase and peroxidase activities.

(3) Proteins Quantification

The protein content was determined by the method of Bradford (1976) using bovine serum albumin (BSA) as a blank.

(4) Polyphenol Oxidase and Peroxidase Activities

(a) Polyphenol Oxidase Activity

Polyphenol oxidase (PPO) activity was determined by measuring the increase in absorbance at $330 \mathrm{~nm}$ using the method of Van Kammen and Broumer (1964). The reaction mixture incubated at $25^{\circ} \mathrm{C}$ was made of: $2.7 \mathrm{~mL}$ of phosphate buffer $(1 / 15 \mathrm{M}, \mathrm{pH} 6.1)$ and $0.3 \mathrm{~mL}$ catechol $(10 \mathrm{mM})$. The reaction was initiated by adding $40 \mu \mathrm{L}$ of enzymatic extract. The enzyme activity was monitored through change of optical density at $330 \mathrm{~nm}$ after $30 \mathrm{~s}$. PPO activity was expressed in unit per $\mu \mathrm{g}$ of proteins content.

\section{(b) Peroxidase Activity}

Peroxidase (POD) activity was determined using the Thorpe and Gaspar method (1978). Guaïacol transformation was followed at $420 \mathrm{~nm}$. A volume $(5 \mathrm{~mL})$ of the reaction mixture $\left(1 \mathrm{~V}\right.$ of $0.2 \% \mathrm{H}_{2} \mathrm{O}_{2} ; 2 \mathrm{~V}$ of $1 \%$ guaïacol; $5 \mathrm{~V}$ 
of $1 / 15 \mathrm{M}$ phosphate buffer $\mathrm{pH}$ 6) was added to $10 \mu \mathrm{L}$ of enzymatic extract. The enzyme activity was evaluated by monitoring optical density change at $420 \mathrm{~nm}$. Peroxidase activity was expressed in unit per $\mu \mathrm{g}$ of proteins contents.

\subsection{Data Analysis}

The data obtained were represented as the mean \pm standard deviation (SD) of three independent experiments. All of the statistical analyses were conducted using SPSS 20.0 software (SPSS, Inc., Chicago, IL, USA). The one-way analysis of variance (ANOVA) with Student-Newman-Keuls tests was used to compare differences between treatment means when significant $\mathrm{F}$ values were observed at $p<0.05$.

\section{Results}

\subsection{Physico-Chemical Parameters of Culture Media}

In this study, variation of physico-chemical parameters of culture media was dependent on different sulphate salts $\left(\mathrm{MgSO}_{4}, \mathrm{~K}_{2} \mathrm{SO}_{4}\right.$ and combination of $\left.\mathrm{MgSO}_{4} / \mathrm{K}_{2} \mathrm{SO}_{4}\right)$ concentrations. It was noticed that $S$. platensis was grown at $27.7 \pm 0.03{ }^{\circ} \mathrm{C}$.

The present study revealed $\mathrm{pH}$ fluctuation along the culture process. Before autoclaving, $\mathrm{pH}$ of all culture media was adjusted to 9.0. From this $\mathrm{pH}$ value, all the treatments displayed a decrease in $\mathrm{pH}$. The difference between the initial $\mathrm{pH}(9)$ and daily $\mathrm{pH}$ (for each culture media) displayed a characteristic pattern similar to all regulatory factors $\left(\mathrm{MgSO}_{4}, \mathrm{~K}_{2} \mathrm{SO}_{4}\right.$ and $\mathrm{MgSO}_{4} / \mathrm{K}_{2} \mathrm{SO}_{4}$ ratio) (Figures $1 \mathrm{a}, 1 \mathrm{~b}$, and $1 \mathrm{c}$ ).
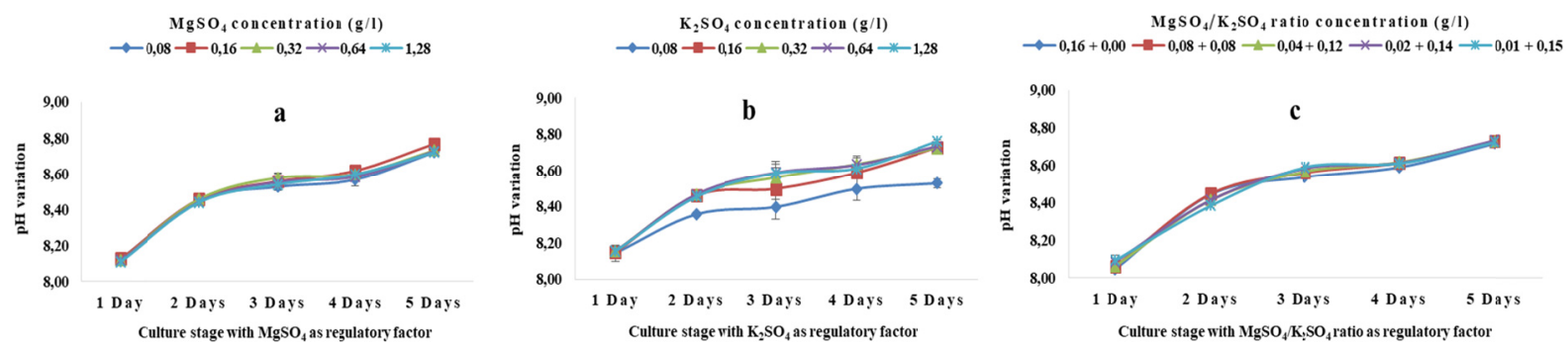

Figure 1. $\mathrm{pH}$ fluctuation in culture media using saparately $\mathrm{MgSO}_{4}(\mathrm{a}), \mathrm{K}_{2} \mathrm{SO}_{4}$ (b) and $\mathrm{MgSO}_{4} / \mathrm{K}_{2} \mathrm{SO}_{4}$ ratio (c) as regulatory factors. Values are expressed in term of: Mean $\pm \mathrm{SD}(\mathrm{n}=3 \times 3=9)$

Conductivity displayed time-increase pattern for all regulatory factors $\left(\mathrm{MgSO}_{4}, \mathrm{~K}_{2} \mathrm{SO}_{4}\right.$ and $\mathrm{MgSO}_{4} / \mathrm{K}_{2} \mathrm{SO}_{4}$ ratio). However, the increase rates varied from one sulphate salt concentration to another and from one regulatory factor $\left(\mathrm{MgSO}_{4}, \mathrm{~K}_{2} \mathrm{SO}_{4}\right.$ and $\mathrm{MgSO}_{4} / \mathrm{K}_{2} \mathrm{SO}_{4}$ ratio) to another. Hence, the conductivity rate showed peaks with $\mathrm{MgSO}_{4}(0.16 \mathrm{~g} / \mathrm{L})$ and $\mathrm{MgSO}_{4} / \mathrm{K}_{2} \mathrm{SO}_{4}(0.02 / 0.14)$. Though, conductivity rate appeared to increase with $\mathrm{K}_{2} \mathrm{SO}_{4}$ content in culture media (Figures 2 and 3 ).
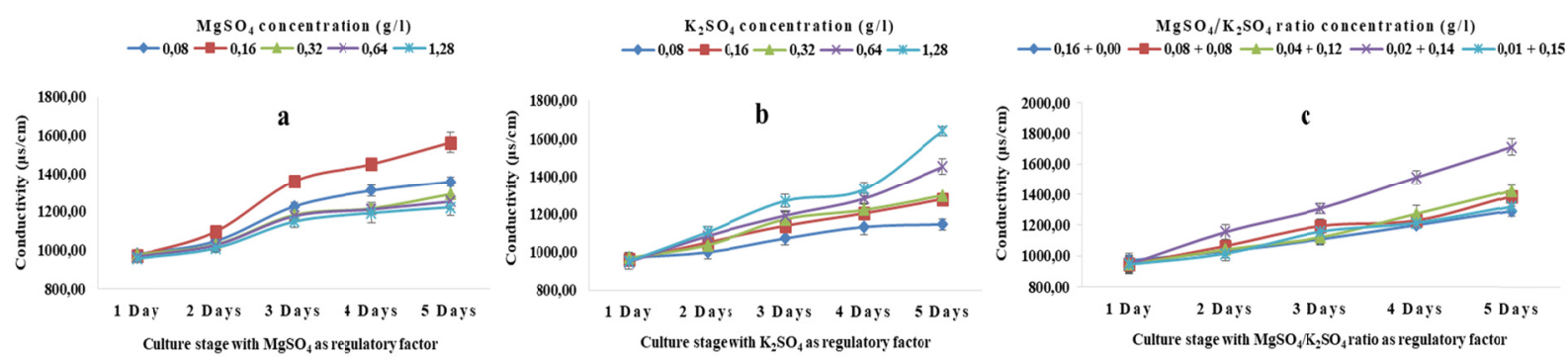

Figure 2. Variation of conductivity (as function of time) in culture media using saparately $\mathrm{MgSO}_{4}$ (a), $\mathrm{K}_{2} \mathrm{SO}_{4}$ (b) and $\mathrm{MgSO}_{4} / \mathrm{K}_{2} \mathrm{SO}_{4}$ ratio (c) as regulatory factors. Values are expressed in term of: Mean $\pm \mathrm{SD}(\mathrm{n}=3 \times 3=9)$ 

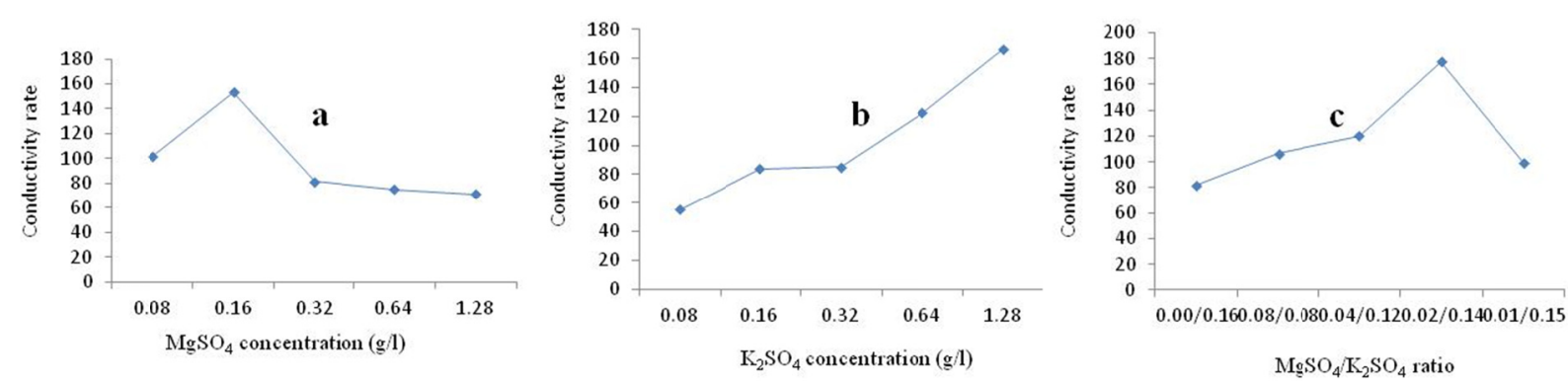

Figure 3. Variation of conductivity rates versus concentrations of regulatory factors $\left(\mathrm{MgSO}_{4}, \mathrm{~K}_{2} \mathrm{SO}_{4}\right.$ and $\mathrm{MgSO}_{4} / \mathrm{K}_{2} \mathrm{SO}_{4}$ ratios). Values are expressed in term of: Mean $\pm \mathrm{SD}(\mathrm{n}=3 \times 3=9)$

Total dissolved solids (TDS) versus time (days) showed an increase pattern as observed with conductivity. TDS rate exhibited a pattern similar to conductivity rate (Figures 4 and 5).
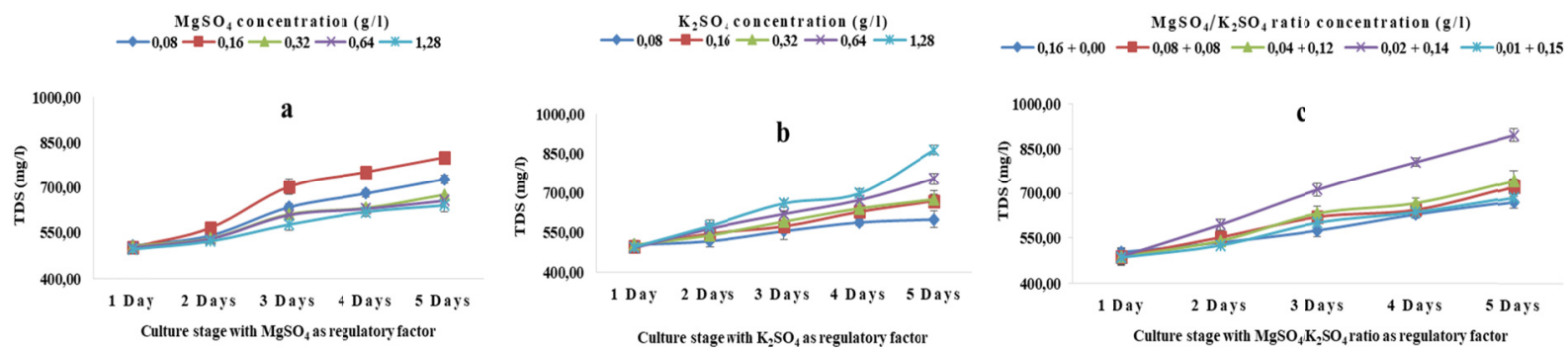

Figure 4. Variation of TDS (as function of time) in culture media using saparately $\mathrm{MgSO}_{4}(\mathrm{a}), \mathrm{K}_{2} \mathrm{SO}_{4}$ (b) and $\mathrm{MgSO}_{4} / \mathrm{K}_{2} \mathrm{SO}_{4}$ ratio (c) as regulatory factors. Values are expressed in term of: Mean $\pm \mathrm{SD}(\mathrm{n}=3 \times 3=9)$
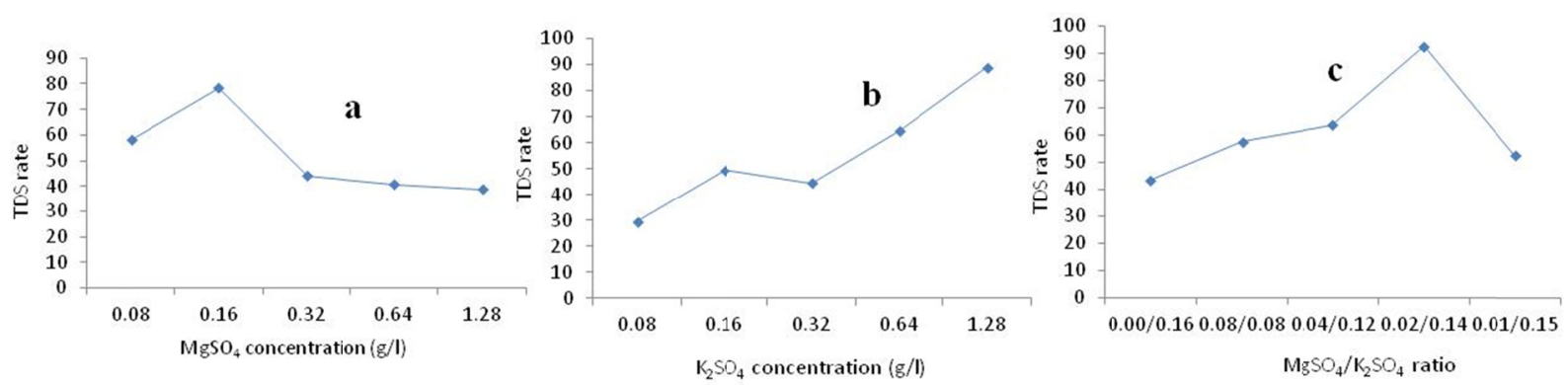

Figure 5. Variation of TDS rates versus concentrations of regulatory factors $\left(\mathrm{MgSO}_{4}, \mathrm{~K}_{2} \mathrm{SO}_{4}\right.$ and $\mathrm{MgSO}_{4} / \mathrm{K}_{2} \mathrm{SO}_{4}$ ratios). Values are expressed in term of: $\operatorname{Mean} \pm \mathrm{SD}(\mathrm{n}=3 \times 3=9)$

\subsection{Microscopic Identification}

S. platensis was identified based on microscopic characteristics like a dark blue-green filament with solitary coiled or spiral shape filaments and typical arrangement of multicellular cylindrical trichomes in an open helix usually of relatively large diameter, sometimes attenuated at the ends and with evident cross-walls floating freely in the medium. The filaments were made up of many cells with clear and visible whorls. The number of whorls varied between 4 and 22, with average of 6 whorls per filament (Figure 6). 

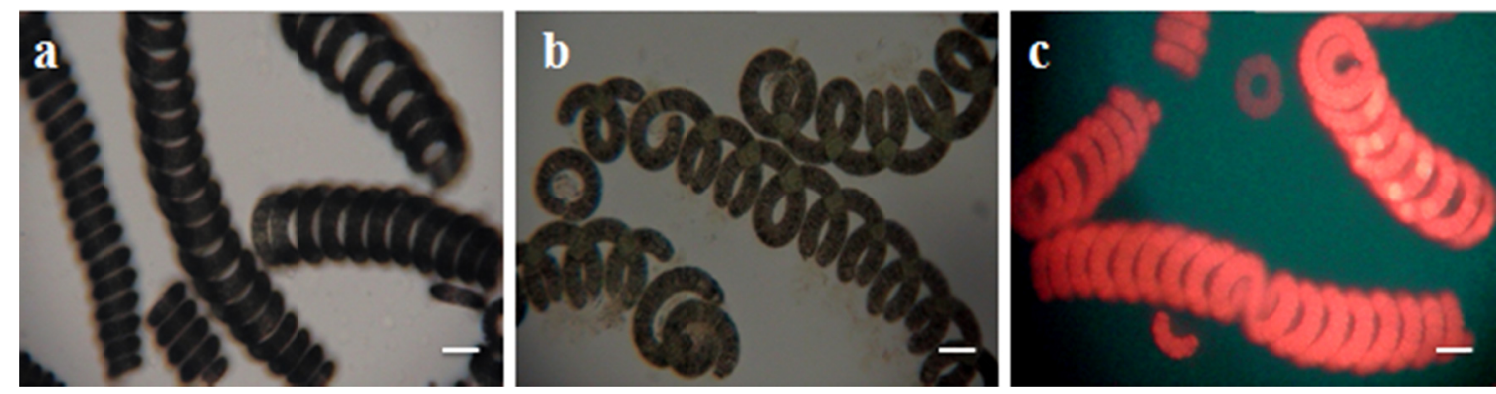

Figure 6. Morphological aspects of Spirulina platensis trichomes obtained from culture pond and grown in laboratory. (a) Regular clonal trichomes; (b) Necridic cell formation in clonal trichomes; (c) Autoflorescence of trichomes. Bar marker $=10 \mu \mathrm{m}$

\subsection{Growth Performance}

In the present study, S. platensis was successfully cultured in five concentrations of $\mathrm{MgSO}_{4}(0.08 ; 0.16 ; 0.32$; 0.64 and $1.28 \mathrm{~g} / \mathrm{L}), \mathrm{K}_{2} \mathrm{SO}_{4}(0.08 ; 0.16 ; 0.32 ; 0.64$ and $1.28 \mathrm{~g} / \mathrm{L})$ and $\mathrm{MgSO}_{4} / \mathrm{K}_{2} \mathrm{SO}_{4}$ ratios $(0.16 / 0.00,0.08 / 0.08$, $0.04 / 0.12,0.02 / 0.14$ and $0.01 / 0.15 \mathrm{~g} / \mathrm{L})$.

Growth of spirulina as number of filaments $\left(\mathrm{N}_{\mathrm{F}}\right)$, number of whorls $\left(\mathrm{N}_{\mathrm{w}}\right)$, cell productivity $\left(\mathrm{P}_{\mathrm{x}}\right)$ and maximum specific growth rate $\left(\mu_{\mathrm{m}}\right)$ showed a sulphate salt concentration dependent response presented in Table 2 . Number of filaments, number of whorls, cell productivity and maximum specific growth rate in $0.16 \mathrm{~g} / \mathrm{L}$ $\mathrm{MgSO}_{4}\left(17569 \pm 1070 \mathrm{~N}_{\mathrm{F}} / \mathrm{mL}, 6 \pm 0 \mathrm{~N}_{\mathrm{W}} / \mathrm{mL}, 0.22 \pm 0.007 \mathrm{mg} / \mathrm{L} /\right.$ day, $0.82 \pm 0.07$ div/day respectively), $1.28 \mathrm{~g} / \mathrm{L}$ $\mathrm{K}_{2} \mathrm{SO}_{4}\left(17737 \pm 251 \mathrm{~N}_{\mathrm{F}} / \mathrm{mL}, 6 \pm 0 \mathrm{~N}_{\mathrm{W}} / \mathrm{mL}, 0.24 \pm 0.008 \mathrm{mg} / \mathrm{L} /\right.$ day, $0.94 \pm 0.08$ div/day respectively) and $0.02 / 0.14$ $\mathrm{g} / \mathrm{L}$ of $\mathrm{MgSO}_{4} / \mathrm{K}_{2} \mathrm{SO}_{4}\left(17972 \pm 637 \mathrm{~N} / \mathrm{mL}, 6 \pm 0 \mathrm{~N}_{\mathrm{W}} / \mathrm{mL}, 0.26 \pm 0.009 \mathrm{mg} / \mathrm{L} /\right.$ day, $0.99 \pm 0.05$ div/day respectively) were significantly higher than those obtained in media supplemented with other concentrations of $\mathrm{MgSO}_{4}$, $\mathrm{K}_{2} \mathrm{SO}_{4}$ and combination of $\mathrm{MgSO}_{4} / \mathrm{K}_{2} \mathrm{SO}_{4}$. A higher concentration of $\mathrm{MgSO}_{4}(1.28 \mathrm{~g} / \mathrm{L})$ and low concentration of $\mathrm{K}_{2} \mathrm{SO}_{4}(0.16 \mathrm{~g} / \mathrm{L})$ could not support the growth of $S$. platensis and resulted in a significantly low number of filaments, cell productivity and maximum specific growth rate. However, with the decrease of the concentrations ratio of $\mathrm{MgSO}_{4} / \mathrm{K}_{2} \mathrm{SO}_{4}$ significant increase of number of filaments, cell productivity and maximum specific growth rate were observed. Therefore, in media supplemented with different concentrations of $\mathrm{MgSO}_{4}, \mathrm{~K}_{2} \mathrm{SO}_{4}$ and the $\mathrm{MgSO}_{4} / \mathrm{K}_{2} \mathrm{SO}_{4}$ combination, the best growth performance was recorded on the medium supplemented with $\mathrm{MgSO}_{4} / \mathrm{K}_{2} \mathrm{SO}_{4}(0.02 / 0.14 \mathrm{~g} / \mathrm{L})$ (Table 2).

Table 2. Number of filaments $\left(\mathrm{N}_{\mathrm{F}}\right)$, number of whorls $\left(\mathrm{N}_{\mathrm{w}}\right)$, biomass $(\mathrm{X})$, cell productivity $\left(\mathrm{P}_{\mathrm{x}}\right)$ and maximum specific growth rate $\left(\mu_{\mathrm{m}}\right)$ of $S$. platensis (Paracas) of culture media on day 5 with different sulphate salts concentrations.

\begin{tabular}{|c|c|c|c|c|c|c|}
\hline Media & Treatment $(\mathrm{g} / \mathrm{L})$ & $\mathrm{N}_{\mathrm{F}}\left(\mathrm{N}_{\mathrm{F}} / \mathrm{mL}\right)$ & $\mathrm{N}_{\mathrm{w}}\left(\mathrm{N}_{\mathrm{W}} / \mathrm{mL}\right)$ & $X(g)$ & $P_{x}(\mathrm{mg} / \mathrm{L} /$ day $)$ & $\mu_{\mathrm{m}}$ (div/day) \\
\hline \multirow{5}{*}{$\mathrm{MgSO}_{4}$} & 0.08 & $14992 \pm 793^{\mathrm{b}}$ & $5 \pm 0^{\mathrm{b}}$ & $1.01 \pm 0.03^{\mathrm{a}}$ & $0.19 \pm 0.005^{\mathrm{b}}$ & $0.76 \pm 0.05^{\mathrm{b}}$ \\
\hline & 0.16 & $17569 \pm 1070^{\mathrm{a}}$ & $6 \pm 0^{\mathrm{a}}$ & $1.06 \pm 0.03^{\mathrm{a}}$ & $0.22 \pm 0.007^{\mathrm{a}}$ & $0.82 \pm 0.07^{\mathrm{a}}$ \\
\hline & 0.32 & $14970 \pm 938^{b}$ & $6 \pm 0^{\mathrm{a}}$ & $0.98 \pm 0.02^{\mathrm{ab}}$ & $0.17 \pm 0.010^{\mathrm{b}}$ & $0.73 \pm 0.06^{\mathrm{b}}$ \\
\hline & 0.64 & $12537 \pm 793^{c}$ & $6 \pm 0^{\mathrm{a}}$ & $0.92 \pm 0.01^{\mathrm{b}}$ & $0.15 \pm 0.011^{\mathrm{bc}}$ & $0.69 \pm 0.09^{\mathrm{bc}}$ \\
\hline & 1.28 & $9428 \pm 901^{\mathrm{d}}$ & $6 \pm 0^{\mathrm{a}}$ & $0.86 \pm 0.02^{\mathrm{c}}$ & $0.13 \pm 0.010^{\mathrm{c}}$ & $0.67 \pm 0.06^{\mathrm{c}}$ \\
\hline \multirow{5}{*}{$\mathrm{K}_{2} \mathrm{SO}_{4}$} & 0.08 & $7899 \pm 295^{\mathrm{e}}$ & $5 \pm 0^{6}$ & $0.80 \pm 0.03^{\mathrm{c}}$ & $0.15 \pm 0.010^{c}$ & $0.55 \pm 0.07^{\mathrm{c}}$ \\
\hline & 0.16 & $10799 \pm 292^{\mathrm{d}}$ & $5 \pm 0^{\mathrm{b}}$ & $1.01 \pm 0.02^{\mathrm{b}}$ & $0.17 \pm 0.010^{\mathrm{c}}$ & $0.78 \pm 0.09^{\mathrm{b}}$ \\
\hline & 0.32 & $12148 \pm 202^{\mathrm{c}}$ & $5 \pm 0^{\mathrm{b}}$ & $1.03 \pm 0.02^{\mathrm{b}}$ & $0.20 \pm 0.011^{\mathrm{b}}$ & $0.81 \pm 0.07^{\mathrm{b}}$ \\
\hline & 0.64 & $14138 \pm 248^{\mathrm{b}}$ & $6 \pm 0^{\mathrm{a}}$ & $1.06 \pm 0.02^{\mathrm{b}}$ & $0.21 \pm 0.012^{\mathrm{b}}$ & $0.90 \pm 0.06^{\mathrm{a}}$ \\
\hline & 1.28 & $17737 \pm 251^{\mathrm{a}}$ & $6 \pm 0^{\mathrm{a}}$ & $1.13 \pm 0.01^{\mathrm{a}}$ & $0.24 \pm 0.008^{\mathrm{a}}$ & $0.94 \pm 0.08^{\mathrm{a}}$ \\
\hline \multirow{5}{*}{$\mathrm{MgSO}_{4}+\mathrm{K}_{2} \mathrm{SO}_{4}$} & $0.16+0.00$ & $9633 \pm 513^{\mathrm{d}}$ & $5 \pm 0^{6}$ & $1.02 \pm 0.01^{\mathrm{b}}$ & $0.19 \pm 0.006^{6}$ & $0.80 \pm 0.06^{\mathrm{c}}$ \\
\hline & $0.08+0.08$ & $14172 \pm 439^{\mathrm{b}}$ & $5 \pm 0^{\mathrm{b}}$ & $1.07 \pm 0.01^{\mathrm{b}}$ & $0.21 \pm 0.010^{\mathrm{b}}$ & $0.91 \pm 0.07^{\mathrm{ab}}$ \\
\hline & $0.04+0.12$ & $14870 \pm 401^{\mathrm{b}}$ & $5 \pm 0^{\mathrm{b}}$ & $1.11 \pm 0.02^{\mathrm{ab}}$ & $0.24 \pm 0.006^{\mathrm{a}}$ & $0.93 \pm 0.07^{\mathrm{ab}}$ \\
\hline & $0.02+0.14$ & $17972 \pm 637^{\mathrm{a}}$ & $6 \pm 0^{\mathrm{a}}$ & $1.24 \pm 0.03^{\mathrm{a}}$ & $0.26 \pm 0.009^{\mathrm{ab}}$ & $0.99 \pm 0.05^{\mathrm{a}}$ \\
\hline & $0.01+0.15$ & $13241 \pm 637^{\mathrm{c}}$ & $5 \pm 0^{\mathrm{b}}$ & $1.04 \pm 0.02^{\mathrm{b}}$ & $0.20 \pm 0.004^{\mathrm{b}}$ & $0.88 \pm 0.06^{\mathrm{b}}$ \\
\hline
\end{tabular}

Note. Data are presented as mean \pm standard deviation (SD). Values in the same column with the same superscript letters $(\mathrm{a}>\mathrm{b}>\mathrm{c}>\mathrm{d}>\mathrm{e})$ are not statistically significant at P-value 0.05 . 
Biomass appeared to increase with culture age. The increase rate was affected by sulphate salt type and concentration. The use of $\mathrm{MgSO}_{4}$ as regulator factor exhibited a peak at $0.16 \mathrm{~g} / \mathrm{L}$. With $\mathrm{K}_{2} \mathrm{SO}_{4}$, rate of biomass accumulation increased with $\mathrm{K}_{2} \mathrm{SO}_{4}$ concentration in culture medium. The ratio $\mathrm{MgSO}_{4} / \mathrm{K}_{2} \mathrm{SO}_{4}$ displayed a peak at $0.02 / 0.14 \mathrm{~g} / \mathrm{L}$ (Figures 7 and 8 ).
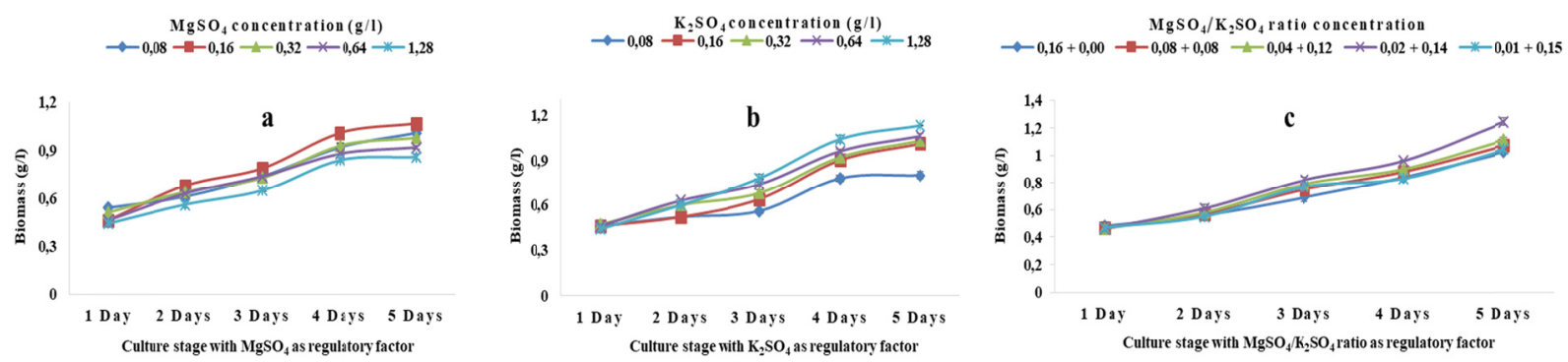

Figure 7. Variation of biomass (as function of time) in culture media using saparately $\mathrm{MgSO}_{4}(\mathrm{a}), \mathrm{K}_{2} \mathrm{SO}_{4}$ (b) and

$\mathrm{MgSO}_{4} / \mathrm{K}_{2} \mathrm{SO}_{4}$ ratio (c) as regulatory factors. Values are expressed in term of: Mean $\pm \mathrm{SD}(\mathrm{n}=3 \times 3=9)$
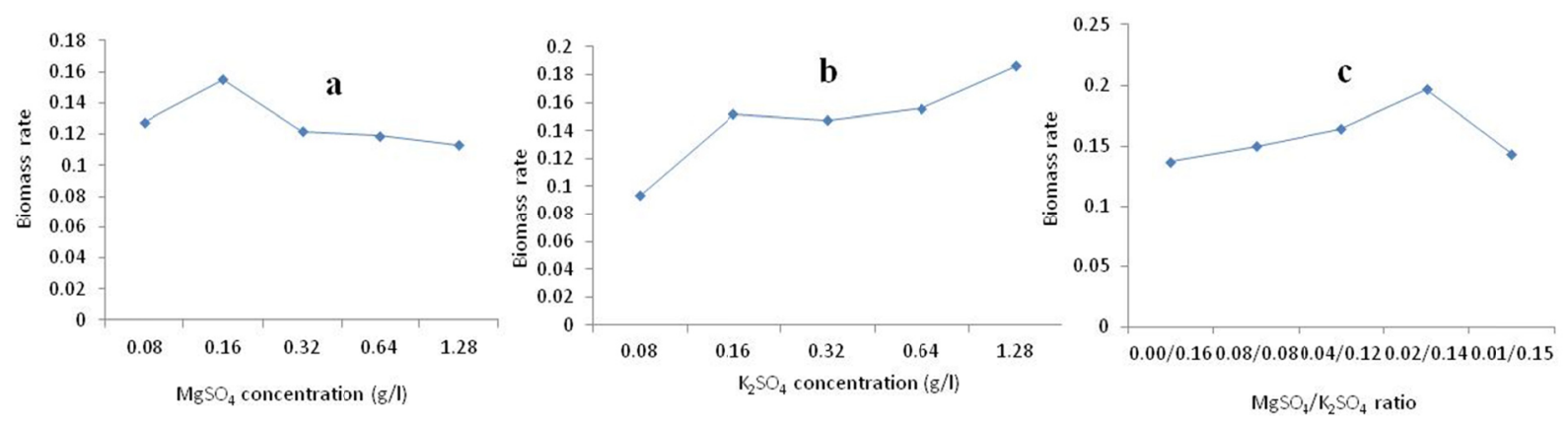

Figure 8. Variation of biomass rates versus concentrations of regulatory factors $\left(\mathrm{MgSO}_{4}, \mathrm{~K}_{2} \mathrm{SO}_{4}\right.$ and $\mathrm{MgSO}_{4} / \mathrm{K}_{2} \mathrm{SO}_{4}$ ratios). Values are expressed in term of: Mean $\pm \mathrm{SD}(\mathrm{n}=3 \times 3=9)$

\subsection{Chemical and Biochemical}

\subsubsection{Chemical Composition of S. platensis Strain Used}

The chemical profile of $S$. platensis strain obtained from the SAGRIC Common Initiative Group (CIG) pond was determined. Results obtained in Table 3 revealed the presence of high level of protein content (63.9\%), ash (12.4\%), calcium (987.4 mg), magnesium (398.7 mg), potassium (1444.0 mg), iron (59.0 mg) and phosphorous $(831.0 \mathrm{mg})$. Whereas lipids content $(2.5 \%)$, fibers $(6.8 \%)$ and sodium $(8.3 \mathrm{mg})$ were found to be lower.

Table 3. Chemical profile of $S$. platensis strain grown in SAGRIC Common Initiative Group (CIG) pond, Douala-Cameroon

\begin{tabular}{ll}
\hline Components & Contents \\
\hline Proteins (\%) & 63.90 \\
Lipids (\%) & 2.50 \\
Fiber (\%) & 6.80 \\
Ash (\%) & 12.40 \\
Potassium (mg/100 g) & 1444.00 \\
Calcium (mg/100 g) & 987.40 \\
Phosphorous (mg/100 g) & 831.00 \\
Magnesium $(\mathrm{mg} / 100 \mathrm{~g})$ & 398.70 \\
Iron $(\mathrm{mg} / 100 \mathrm{~g})$ & 59.00 \\
Sodium & 8.30 \\
\hline
\end{tabular}


3.4.2 Proteins, Cysteine and Reducing Sugars Contents in S. platensis Cultured in Media Supplemented With Sulphate Salts

Proteins, cysteine and reducing sugars contents in $S$. platensis cultured in media supplemented with five concentrations of $\mathrm{MgSO}_{4}(0.08 ; 0.16 ; 0.32 ; 0.64$ and $1.28 \mathrm{~g} / \mathrm{L}), \mathrm{K}_{2} \mathrm{SO}_{4}(0.08 ; 0.16 ; 0.32 ; 0.64$ and $1.28 \mathrm{~g} / \mathrm{L})$ and the $\mathrm{MgSO}_{4} / \mathrm{K}_{2} \mathrm{SO}_{4}$ combination $(0.16 / 0.00,0.08 / 0.08,0.04 / 0.12,0.02 / 0.14$ and $0.01 / 0.15 \mathrm{~g} / \mathrm{L})$ were monitored and in media supplemented with different concentrations of $\mathrm{MgSO}_{4}, \mathrm{~K}_{2} \mathrm{SO}_{4}$ and the $\mathrm{MgSO}_{4} / \mathrm{K}_{2} \mathrm{SO}_{4}$ combination, the best proteins, cysteine and reducing sugars contents were recorded on the medium supplemented with $\mathrm{MgSO}_{4} / \mathrm{K}_{2} \mathrm{SO}_{4}(0.02 / 0.14 \mathrm{~g} / \mathrm{L})$ (Table 4$)$.

Table 4. Protein, cysteine and reducing sugars contents of $S$. platensis (Paracas) at 5 days of growth in media with different $\mathrm{MgSO}_{4}, \mathrm{~K}_{2} \mathrm{SO}_{4}$ and combination of $\mathrm{MgSO}_{4}+\mathrm{K}_{2} \mathrm{SO}_{4}$ concentrations

\begin{tabular}{lllll}
\hline Media & Treatment $(\mathrm{g} / \mathrm{L})$ & Protein $(\mathrm{mg} / \mathrm{L})$ & Cysteine $(\mathrm{mg} / \mathrm{L})$ & Reducing sugars $(\mathrm{mg} / \mathrm{L})$ \\
\hline & 0.08 & $837.09 \pm 21.34^{\mathrm{b}}$ & $82.61 \pm 5.12^{\mathrm{c}}$ & $35.22 \pm 0.03^{\mathrm{a}}$ \\
& 0.16 & $933.02 \pm 29.91^{\mathrm{a}}$ & $100.01 \pm 4.03^{\mathrm{b}}$ & $28.63 \pm 0.03^{\mathrm{b}}$ \\
$\mathrm{MgSO}_{4}$ & 0.32 & $733.70 \pm 20.85^{\mathrm{bc}}$ & $104.35 \pm 4.50^{\mathrm{b}}$ & $26.73 \pm 0.02^{\mathrm{b}}$ \\
& 0.64 & $696.35 \pm 33.01^{\mathrm{c}}$ & $104.44 \pm 4.58^{\mathrm{b}}$ & $26.07 \pm 0.01^{\mathrm{b}}$ \\
& 1.28 & $652.33 \pm 37.74^{\mathrm{c}}$ & $117.40 \pm 4.46^{\mathrm{a}}$ & $25.60 \pm 0.02^{\mathrm{bc}}$ \\
$\mathrm{K}_{2} \mathrm{SO}_{4}$ & 0.08 & $748.37 \pm 25.59^{\mathrm{c}}$ & $69.57 \pm 4.59^{\mathrm{c}}$ & $36.51 \pm 0.81^{\mathrm{a}}$ \\
& 0.16 & $800.40 \pm 35.03^{\mathrm{bc}}$ & $73.91 \pm 4.80^{\mathrm{c}}$ & $32.62 \pm 0.31^{\mathrm{b}}$ \\
& 0.32 & $896.45 \pm 35.86^{\mathrm{b}}$ & $78.26 \pm 4.50^{\mathrm{c}}$ & $30.24 \pm 1.17^{\mathrm{b}}$ \\
$\ldots$ & 0.64 & $933.80 \pm 36.11^{\mathrm{a}}$ & $95.65 \pm 4.43^{\mathrm{b}}$ & $28.82 \pm 0.61^{\mathrm{bc}}$ \\
& 1.28 & $986.19 \pm 38.68^{\mathrm{a}}$ & $113.05 \pm 3.68^{\mathrm{a}}$ & $26.28 \pm 0.72^{\mathrm{c}}$ \\
$\mathrm{MgSO}_{4}+\mathrm{K}_{2} \mathrm{SO}_{4}$ & $0.16+0.00$ & $763.04 \pm 38.11^{\mathrm{d}}$ & $100.07 \pm 3.83^{\mathrm{b}}$ & $27.87 \pm 0.87^{\mathrm{c}}$ \\
& $0.08+0.08$ & $859.76 \pm 19.63^{\mathrm{bc}}$ & $112.06 \pm 3.33^{\mathrm{ab}}$ & $32.30 \pm 1.18^{\mathrm{bc}}$ \\
& $0.04+0.12$ & $913.13 \pm 25.56^{\mathrm{b}}$ & $116.35 \pm 3.83^{\mathrm{ab}}$ & $38.16 \pm 0.92^{\mathrm{a}}$ \\
& $0.02+0.14$ & $1067.20 \pm 26.58^{\mathrm{a}}$ & $122.35 \pm 5.42^{\mathrm{a}}$ & $34.29 \pm 0.84^{\mathrm{b}}$ \\
& $0.01+0.15$ & $807.74 \pm 34.89^{\mathrm{c}}$ & $99.05 \pm 5.42^{\mathrm{b}}$ & $27.94 \pm 0.53^{\mathrm{c}}$
\end{tabular}

Note. Data are presented as mean \pm standard deviation (SD). Values in the same column with the same superscript letters $(\mathrm{a}>\mathrm{b}>\mathrm{c}>\mathrm{d})$ are not statistically significant at P-value 0.05 .

Protein contents of $S$. platensis biomass increased with culture age independently of sulphate salt type and concentration. However, the increase rate of protein contents appeared to be affected by sulphate salt (content and type) in culture medium. Hence, the use of $\mathrm{MgSO}_{4}$ as regulatory factor exhibited the lowest protein contents increase rate between 0.16 and $0.64 \mathrm{~g} / \mathrm{L} \mathrm{MgSO}_{4}$. When $\mathrm{K}_{2} \mathrm{SO}_{4}$ was as regulatory factor, a peak of protein contents increase rate was obtained with $0.16 \mathrm{~g} / \mathrm{L}$ protein contents increase rate. A peak of protein contents increase rate was also observed with $\mathrm{MgSO}_{4} / \mathrm{K}_{2} \mathrm{SO}_{4}$ combination (0.02/0.14) (Figures 9 and 10).
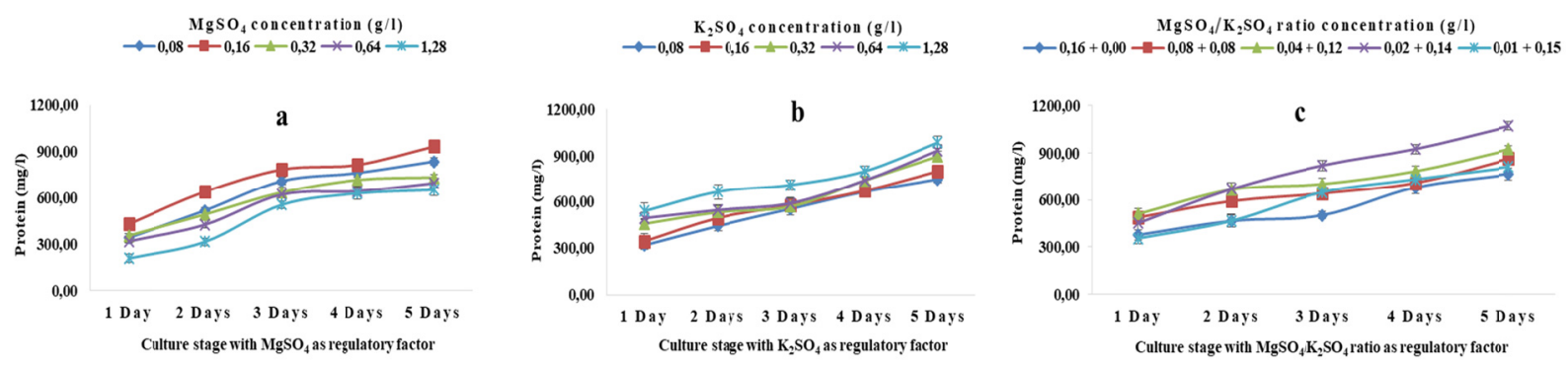

Figure 9. Proteins contents (as function of time) of S. platensis cultured in media supplemented with $\mathrm{MgSO}_{4}$ (a), $\mathrm{K}_{2} \mathrm{SO}_{4}$ (b) and $\mathrm{MgSO}_{4} / \mathrm{K}_{2} \mathrm{SO}_{4}$ ratio (c). Values are expressed in term of: Mean $\pm \mathrm{SD}(\mathrm{n}=3 \times 3=9)$ 

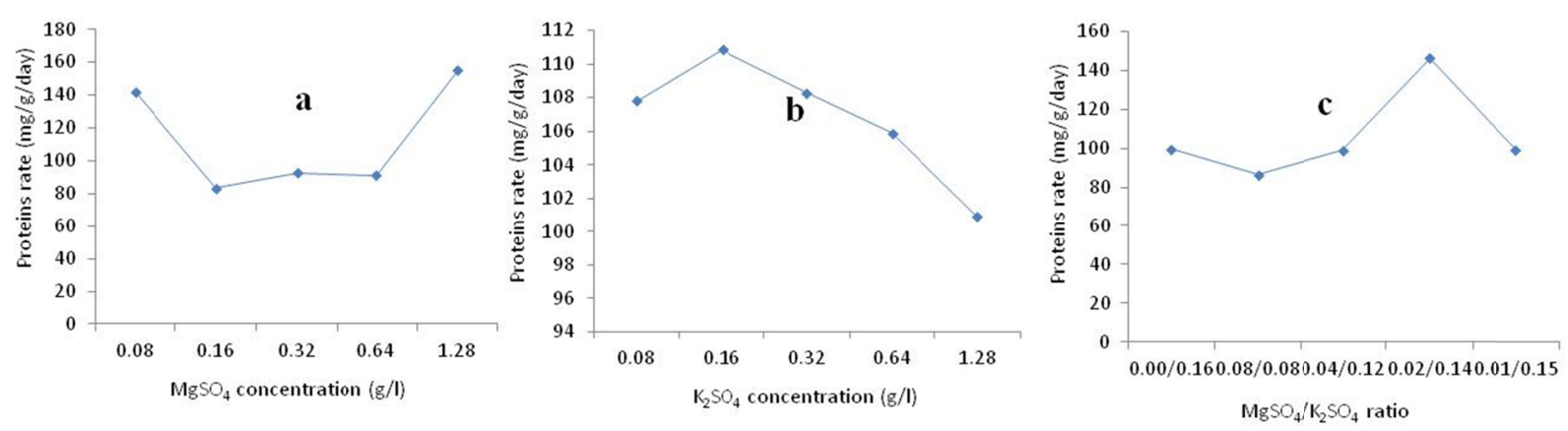

Figure 10. Variation of proteins contents rates versus concentrations of regulatory factors $\left(\mathrm{MgSO}_{4}, \mathrm{~K}_{2} \mathrm{SO}_{4}\right.$ and $\mathrm{MgSO}_{4} / \mathrm{K}_{2} \mathrm{SO}_{4}$ ratios). Values are expressed in term of: Mean $\pm \mathrm{SD}(\mathrm{n}=3 \times 3=9)$

As with protein content, an accumulation (with time) of cysteine contents in S. platensis was observed in all culture media. Though, the accumulation rate was varied with sulphate salt type and concentration. Peak of cysteine accumulation rate appeared at $0.16 \mathrm{MgSO}_{4}$ and $\mathrm{MgSO}_{4} / \mathrm{K}_{2} \mathrm{SO}_{4}(0.02 / 0.14)$. These peaks seemed to match with peaks of protein contents increase rate (Figures 11 and 12).
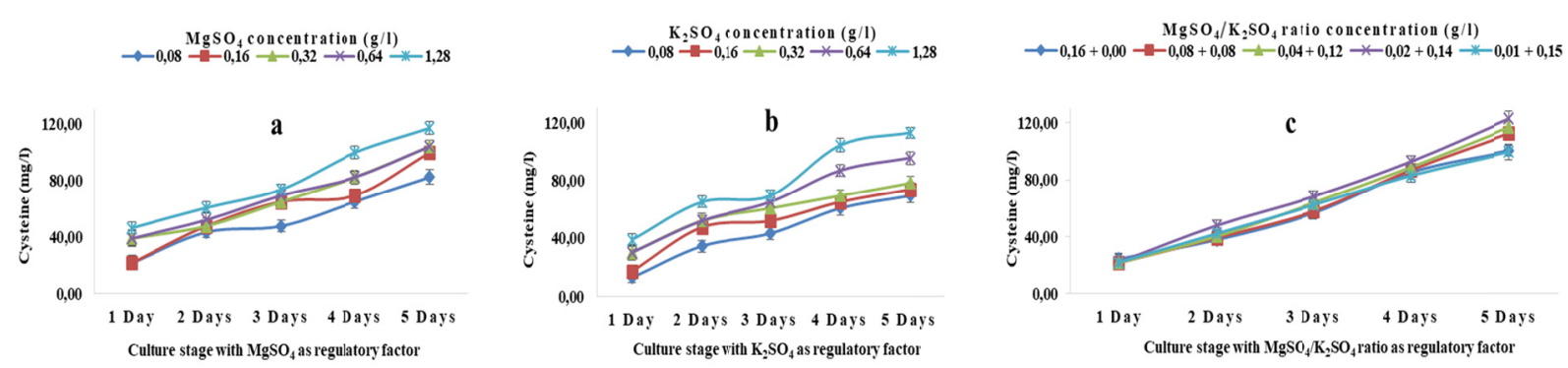

Figure 11. Cysteine contents (as function of time) of $S$. platensis cultured in media supplemented with $\mathrm{MgSO}_{4}$

(a), $\mathrm{K}_{2} \mathrm{SO}_{4}$ (b) and $\mathrm{MgSO}_{4} / \mathrm{K}_{2} \mathrm{SO}_{4}$ ratio (c). Values are expressed in term of: Mean $\pm \mathrm{SD}(\mathrm{n}=3 \times 3=9)$
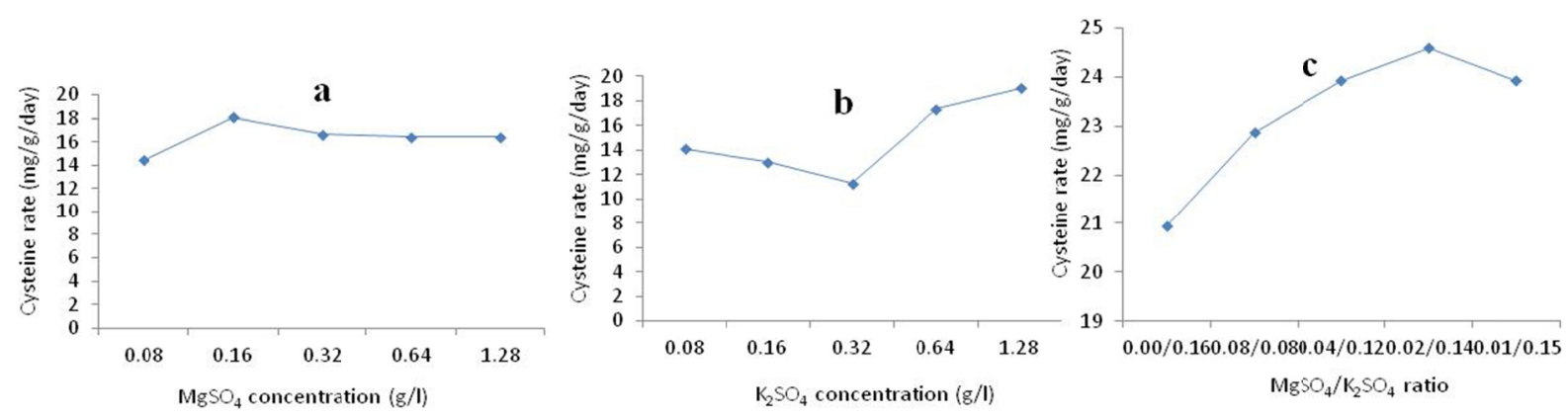

Figure 12. Variation of cysteine contents rates versus concentrations of regulatory factors $\left(\mathrm{MgSO}_{4}, \mathrm{~K}_{2} \mathrm{SO}_{4}\right.$ and $\mathrm{MgSO}_{4} / \mathrm{K}_{2} \mathrm{SO}_{4}$ ratios). Values are expressed in term of Mean $\pm \mathrm{SD}(\mathrm{n}=3 \times 3=9)$

Reducing sugars contents increased with culture ages for all culture media. But, when $\mathrm{MgSO}_{4}$ or $\mathrm{K}_{2} \mathrm{SO}_{4}$ were used separately as regulatory factors, the increase rate of reducing sugars contents displayed an opposite pattern compared to cysteine contents rate pattern (Figures 13 and 14). 

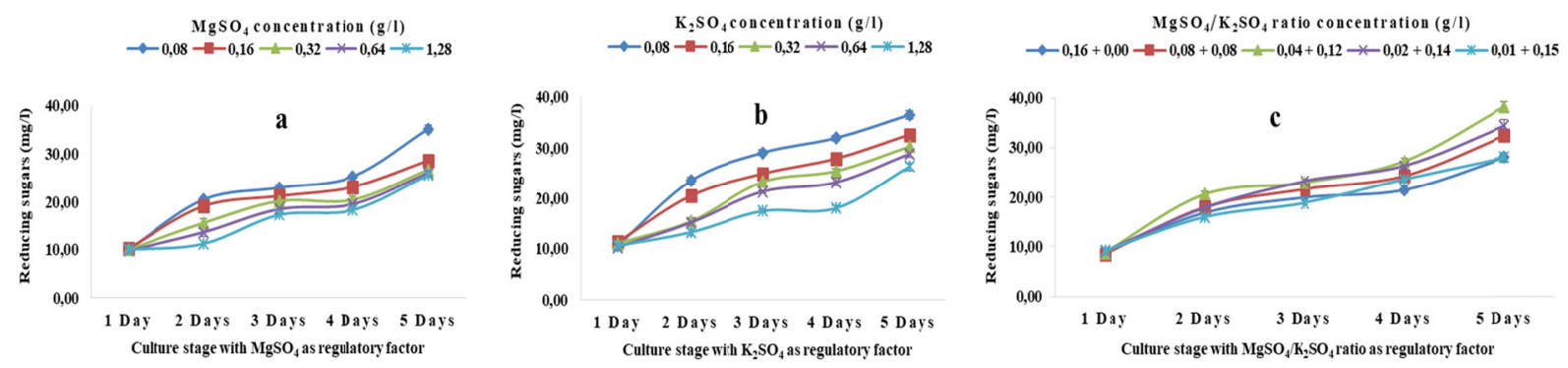

Figure 13. Reducing sugars contents (as function of time) of S. platensis cultured in media supplemented with $\mathrm{MgSO}_{4}$ (a), $\mathrm{K}_{2} \mathrm{SO}_{4}$ (b) and $\mathrm{MgSO}_{4} / \mathrm{K}_{2} \mathrm{SO}_{4}$ ratio (c). Values are expressed in term of: Mean $\pm \mathrm{SD}(\mathrm{n}=3 \times 3=9)$
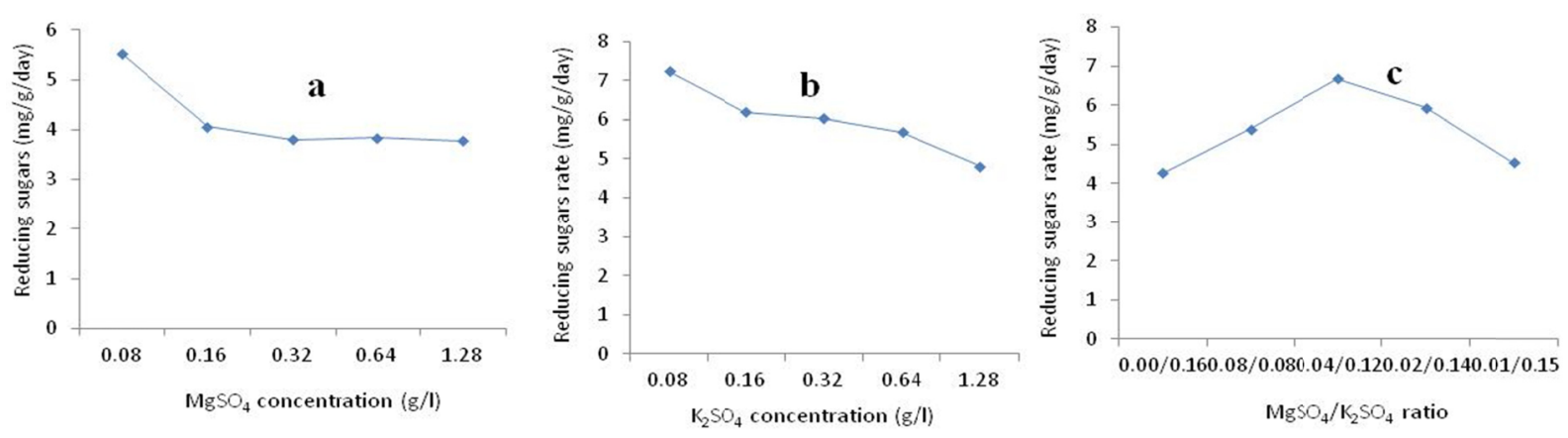

Figure. 14. Variation of reducing sugars contents rates versus concentrations of regulatory factors $\left(\mathrm{MgSO}_{4}\right.$, $\mathrm{K}_{2} \mathrm{SO}_{4}$ and $\mathrm{MgSO}_{4} / \mathrm{K}_{2} \mathrm{SO}_{4}$ ratios $)$. Values are expressed in term of: $\mathrm{Mean} \pm \mathrm{SD}(\mathrm{n}=3 \times 3=9)$

\subsection{Antioxidant Enzymes Activities in S. platensis Cultured in Media Supplemented With Sulphate Salts}

The activities of antioxidant enzymes (PPO and POD) increased with cultures age in all sulphate salt types and concentrations. But, the increase rate of polyphenol oxidase activity decreases when the concentration of $\mathrm{MgSO}_{4}$ increases. Reversely, increase rate of polyphenol oxidase activity increases with $\mathrm{K}_{2} \mathrm{SO}_{4}$ concentration in culture media. The use of $\mathrm{MgSO}_{4} / \mathrm{K}_{2} \mathrm{SO}_{4}$ as regulatory factor displayed a peak of increase rate of polyphenol oxidase activity at $0.02 / 0.14\left(\mathrm{MgSO}_{4} / \mathrm{K}_{2} \mathrm{SO}_{4}\right)$. This peak matches with proteins and cysteine contents rates for the same regulatory factor $\left(\mathrm{MgSO}_{4} / \mathrm{K}_{2} \mathrm{SO}_{4}\right)$ (Figures 15 and 16).
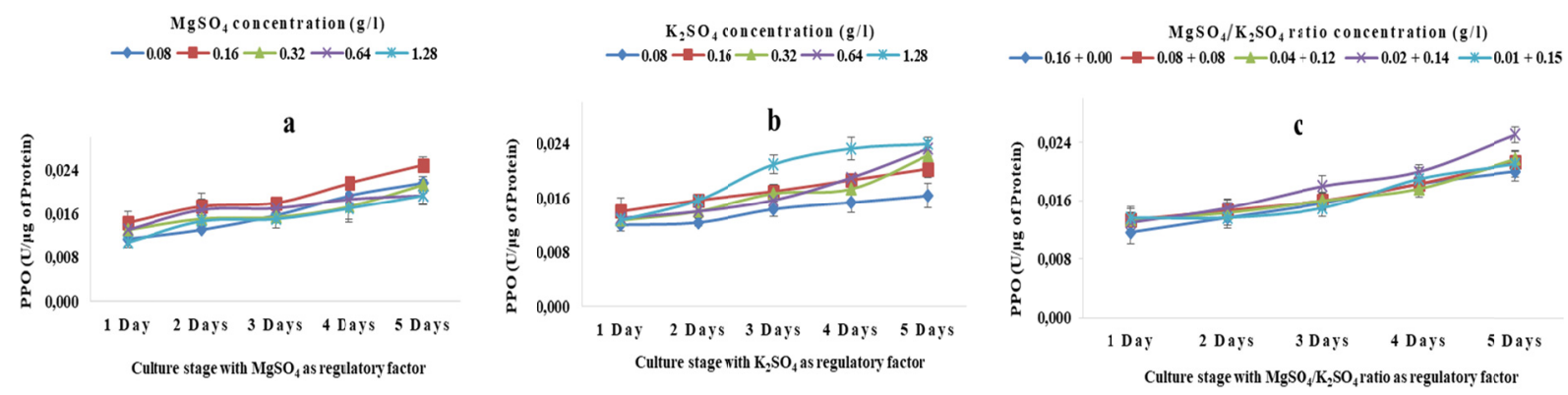

Figure 15. Polyphenol oxidase activity (as function of time) of S. platensis cultured in media supplemented with $\mathrm{MgSO}_{4}(\mathrm{a}), \mathrm{K}_{2} \mathrm{SO}_{4}$ (b) and $\mathrm{MgSO}_{4} / \mathrm{K}_{2} \mathrm{SO}_{4}$ ratio (c). Values are expressed in term of: Mean $\pm \mathrm{SD}(\mathrm{n}=3 \times 3=9)$ 


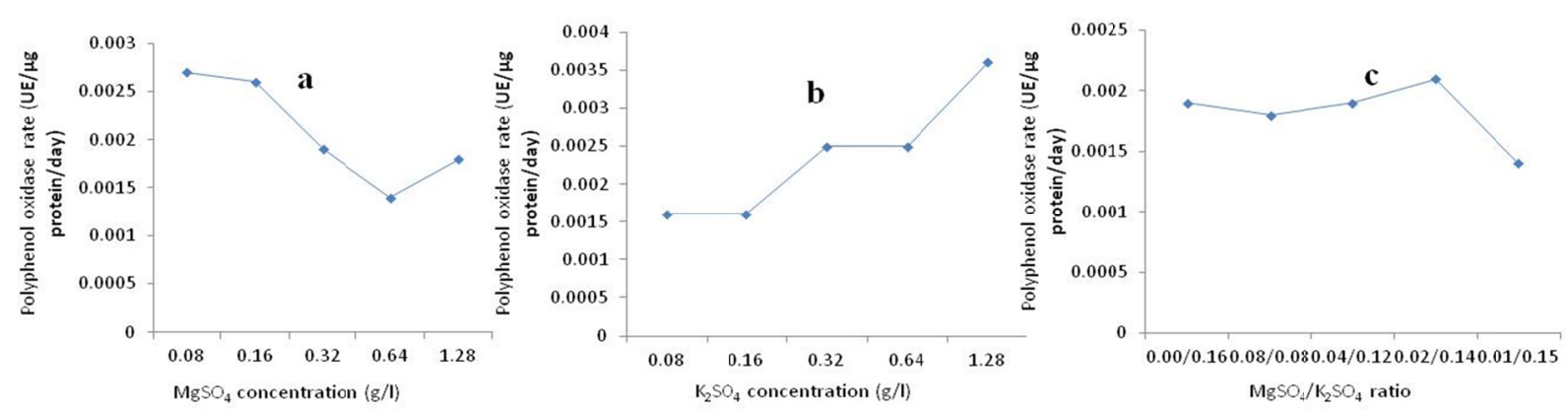

Figure 16. Variation of polyphenol oxidase activity rates versus concentrations of regulatory factors $\left(\mathrm{MgSO}_{4}\right.$, $\mathrm{K}_{2} \mathrm{SO}_{4}$ and $\mathrm{MgSO}_{4} / \mathrm{K}_{2} \mathrm{SO}_{4}$ ratios $)$. Values are expressed in term of: $\mathrm{Mean} \pm \mathrm{SD}(\mathrm{n}=3 \times 3=9)$

Variation in peroxidase activity was observed with time and sulphate salt types and concentrations. The increase activity rate of peroxidase exhibited peaks with $\mathrm{MgSO}_{4}(0.16 \mathrm{~g} / \mathrm{L}), \mathrm{K}_{2} \mathrm{SO}_{4}(0.16 \mathrm{~g} / \mathrm{L})$ and $\mathrm{MgSO}_{4} / \mathrm{K}_{2} \mathrm{SO}_{4}$ $(0.02 / 0.14)$ (Figures 17 and 18).
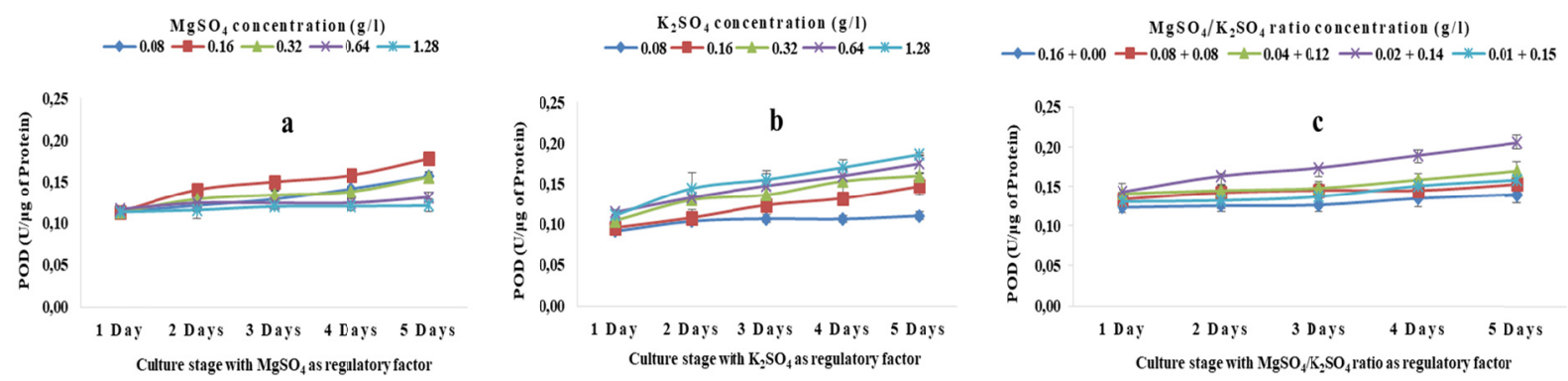

Figure 17. Peroxidase activity (as function of time) of $S$. platensis cultured in media supplemented with $\mathrm{MgSO}_{4}$

(a), $\mathrm{K}_{2} \mathrm{SO}_{4}$ (b) and $\mathrm{MgSO}_{4} / \mathrm{K}_{2} \mathrm{SO}_{4}$ ratio (c). Values are expressed in term of: Mean $\pm \mathrm{SD}(\mathrm{n}=3 \times 3=9)$
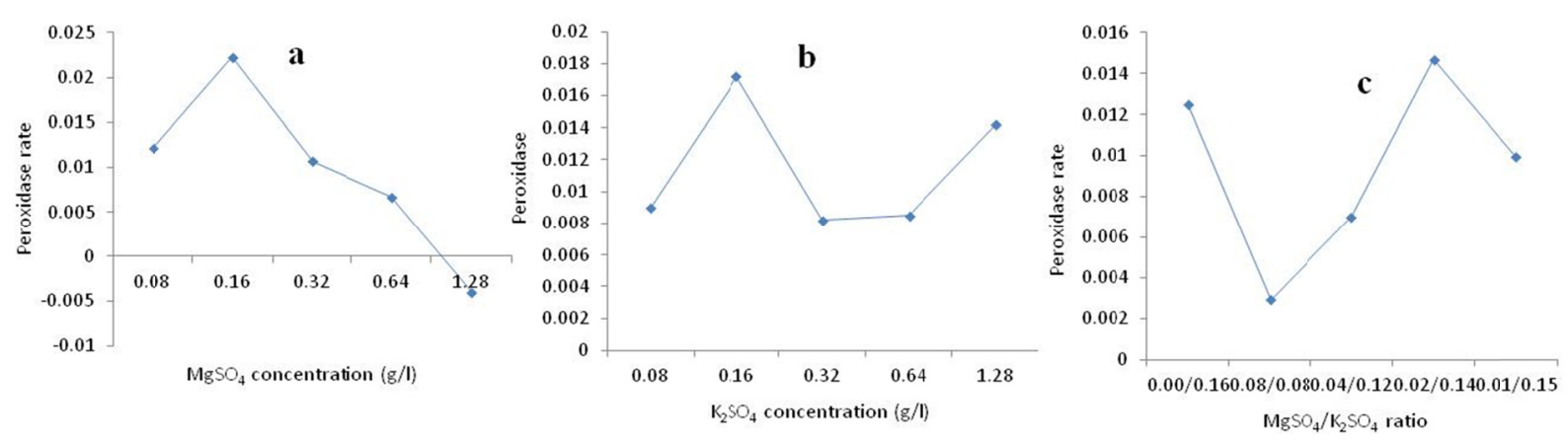

Figure 18. Variation of peroxidase activity rates versus concentrations of regulatory factors $\left(\mathrm{MgSO}_{4}, \mathrm{~K}_{2} \mathrm{SO}_{4}\right.$ and $\mathrm{MgSO}_{4} / \mathrm{K}_{2} \mathrm{SO}_{4}$ ratios). Values are expressed in term of: Mean $\pm \mathrm{SD}(\mathrm{n}=3 \times 3=9)$

Correlation analysis between variables was conducted. When $\mathrm{K}_{2} \mathrm{SO}_{4}$ was used as regulatory factor, negative and significant correlations were observed between $\mathrm{K}_{2} \mathrm{SO}_{4}$ and reducing sugars; indicating that, $\mathrm{K}_{2} \mathrm{SO}_{4}$ supply in culture media lead to the use of reducing sugars. Also, negative and highly significant correlations were obtained between reducing sugars contents and biomass or cysteine contents; showing that, $\mathrm{K}_{2} \mathrm{SO}_{4}$ supply promote the use of reducing sugars for the synthesis of cysteine which increases biomass. Polyphenol oxidase activity appeared to be also negatively correlated to reducing sugars. In summary, correlations found between variables indicate dependant link between $\mathrm{K}_{2} \mathrm{SO}_{4}$ supply and biochemical status and biomass of spirulina (Table 5). Similar correlations (but not always significant) were also found when using $\mathrm{MgSO}_{4}$ or $\mathrm{MgSO}_{4} / \mathrm{K}_{2} \mathrm{SO}_{4}$ as regulatory factors. 
Table 5. Pearson correlation between $\mathrm{K}_{2} \mathrm{SO}_{4}$, Conductivity, TDS, number of filament, Density, Biomass, Proteins, Cysteine, Reducing sugars, Polyphenol oxidase and Peroxidase.

\begin{tabular}{|c|c|c|c|c|c|c|c|c|c|c|c|c|}
\hline & & $\mathrm{K}_{2} \mathrm{SO}_{4}$ & Conductivity & TDS & $\begin{array}{l}\text { No. of } \\
\text { filament }\end{array}$ & Density & Biomass & Proteins & Cysteine & $\begin{array}{l}\text { Reducing } \\
\text { sugars }\end{array}$ & $\begin{array}{l}\text { Polyphenol } \\
\text { oxidase }\end{array}$ & Peroxidase \\
\hline \multirow{2}{*}{$\mathrm{K}_{2} \mathrm{SO}_{4}$} & Corr & 1 & & & & & & & & & & \\
\hline & Sig. & & & & & & & & & & & \\
\hline \multirow{2}{*}{ Conductivity } & Corr & $.979^{* *}$ & 1 & & & & & & & & & \\
\hline & Sig. & .004 & & & & & & & & & & \\
\hline \multirow{2}{*}{ TDS } & Corr & $.961^{* *}$ & $.995^{* *}$ & -- & & & & & & & & \\
\hline & Sig. & .009 & .000 & & & & & & & & & \\
\hline \multirow{2}{*}{ No. of filament } & Corr & $.970^{* *}$ & $.998^{* *}$ & .990 & 1 & & & & & & & \\
\hline & Sig. & .006 & .000 & .001 & & & & & & & & \\
\hline \multirow{2}{*}{ Density } & Corr & $.997^{* *}$ & $984^{* * *}$ & $.965^{* * *-}$ & $.978^{* *-1}$ & 1 & & & & & & \\
\hline & Sig. & .000 & .002 & .008 & .004 & & & & & & & \\
\hline \multirow{2}{*}{ Biomass } & Corr & .805 & $.889^{*}$ & $.911^{*}$ & $.893^{*}$ & .802 & 1 & & & & & \\
\hline & Sig. & .100 & .044 & .032 & .041 & .103 & & & & & & \\
\hline \multirow{2}{*}{ Proteins } & Corr & $-.937^{*}$ & -.854 & -.812 & -.840 & $-.933^{*}$ & -.551 & 1 & & & & \\
\hline & Sig. & .019 & .066 & .095 & .075 & .021 & .335 & & & & & \\
\hline \multirow{2}{*}{ Cysteine } & Corr & .839 & .826 & .812 & .818 & .866 & .513 & -.855 & 1 & & & \\
\hline & Sig. & .076 & .085 & .095 & .090 & .058 & .377 & .065 & & & & \\
\hline \multirow{2}{*}{ Reducing sugars } & Corr & $-.913^{*}$ & $-.961^{* *-}$ & $-.965^{* *}$ & $-.964^{* *-1}$ & $-.911^{*}$ & $-.974^{* *}$ & .721 & -.644 & 1 & & \\
\hline & Sig. & .030 & .009 & .008 & .008 & .032 & .005 & .169 & .241 & & & \\
\hline \multirow{2}{*}{ Polyphenol oxidase } & Corr & $.954^{*}$ & $.914^{*}$ & $.879^{*}$ & $.912^{*}$ & $.940^{*}$ & .785 & $-.902^{*}$ & .668 & $-.898^{*}$ & 1 & \\
\hline & Sig. & .012 & .030 & .050 & .031 & .017 & .115 & .036 & .218 & .039 & & \\
\hline \multirow{2}{*}{ Peroxidase } & Corr & .176 & .262 & .355 & .219 & .161 & .438 & .041 & .139 & -.308 & .003 & 1 \\
\hline & Sig. & .778 & .670 & .557 & .723 & .795 & .461 & .948 & .823 & .614 & .997 & \\
\hline
\end{tabular}

Note. ${ }^{* *}$ Significant of correlation at 0.01 probability level, ${ }^{*}$ Significant of correlation at 0.05 probability level.

\section{Discussion}

This study highlights that sulphate nutrition has an important influence on the growth performance and biochemical status including antioxidant enzymes activity of the cyanobacterium Spirulina platensis.

In the mass culture of microalgae, the medium quality is one of the key factors controlling growth, productivity and biochemical status (Madkour et al., 2012). The algae S. platensis has been studied with the basic aim of screening for magnesium sulphate $\left(\mathrm{MgSO}_{4}\right)$ and potassium sulphate $\left(\mathrm{K}_{2} \mathrm{SO}_{4}\right)$ concentrations.

The cyanobacterium $S$. platensis was cultured at $\mathrm{pH} 9$ and temperature of $28{ }^{\circ} \mathrm{C}$. However, we noticed progressive increase of conductivity and total dissolved solids (TDS) in media with different concentration of $\mathrm{MgSO}_{4}, \mathrm{~K}_{2} \mathrm{SO}_{4}$ and the $\mathrm{MgSO}_{4} / \mathrm{K}_{2} \mathrm{SO}_{4}$ combination. This increase of conductivity and total dissolved solids (TDS) could be explained by the presence of electrically charged atoms which increase with the evaporation of water in media and to the change of the other variables of the culture media due to uptake of nutrients brought by the different concentration of sulphate salt (Anna, 2018).

The morphological feature of $S$. platensis identified like a blue-green filamentous cyanobacterium was reported by Luo and Jiang (2015). Microscopic analysis revealed that the number of whorls and filaments are influenced by sulphate salts concentration. Growth of $S$. platensis as number of filaments, biomass, cell productivity and maximum specific growth rate in $0.16 \mathrm{~g} / \mathrm{L} \mathrm{MgSO}_{4}, 1.28 \mathrm{~g} / \mathrm{L} \mathrm{K} \mathrm{K}_{2} \mathrm{SO}_{4}$ and $0.02 / 0.14 \mathrm{~g} / \mathrm{L} \mathrm{MgSO}_{4} / \mathrm{K}_{2} \mathrm{SO}_{4}$ combination was significantly higher than those obtained in media supplemented with others concentrations of $\mathrm{MgSO}_{4}, \mathrm{~K}_{2} \mathrm{SO}_{4}$ and combination of $\mathrm{MgSO}_{4} / \mathrm{K}_{2} \mathrm{SO}_{4}$ (Table 2). These results could be explained by the fact that the higher concentration of $\mathrm{MgSO}_{4}(0.32,0.64$ and $1.28 \mathrm{~g} / \mathrm{L})$ have negative effect in media involving the reduction of photosynthetic activity of S. platensis (Nyabuto et al., 2015). According to Ndjouondo et al. (2017), 0.1 and $0.2 \mathrm{~g} / \mathrm{L}$ of magnesium sulphate are used as optimum concentration for growth of $S$. platensis and growth delay was observed at concentration higher than $0.2 \mathrm{~g} / \mathrm{L}$ and the low biomass yield at the highest concentration could be attributed to substrate toxicity (Wakte et al., 2011). The lower number of filaments, biomass, cell productivity and maximum specific growth rate at lower concentration of $\mathrm{K}_{2} \mathrm{SO}_{4}(0.16 \mathrm{~g} / \mathrm{L})$ are in agreement with those reported by Wagih El-Shouny et al. (2015) which showed that the reduction of sulphur in the culture medium involved non significant reduction in the growth of the biomass and productivity of $S$. platensis. Moreover low yield of growth recorded in media in with low potassium sulphate concentrations could be 
because sulphur deficiency could cause a reduction in the cell multiplication while influencing on metabolism of carbon in photosynthetic activity as reported by Carfagna et al. (2015) to Chlorella sorokiniana. Therefore, in media supplemented with different concentrations of sulphate salts, the best number of filaments, biomass, cell productivity and maximum specific growth rate were recorded on medium supplemented with $\mathrm{MgSO}_{4} / \mathrm{K}_{2} \mathrm{SO}_{4}$ $(0.02 / 0.14 \mathrm{~g} / \mathrm{L})$. This could be due to the presence of mineral nutrients $(\mathrm{K}$ and $\mathrm{Mg})$ brought by the $\mathrm{MgSO}_{4} / \mathrm{K}_{2} \mathrm{SO}_{4}$ combination that might play a critical role in the metabolic activities, as essential components of enzymes and other cellular components (Kaushik et al,. 2006) and the presence in the medium of ions $\mathrm{Mg}^{2+}$ and $\mathrm{K}^{+}$which could play a significant role in the mechanism of photosynthesis.

Culture medium composition has been reported as one of the most important factors with determining role in biochemical status of microalgae (Çelekli et al., 2016). The biochemical profile of S. platensis strain in pond of SAGRIC Common Initiative Group (CIG) farm, Douala (Cameroon) has shown highest content of protein (63.9\%) compared to the $37.5 \%$ of protein harvested by Ama Moor et al. (2016) in Nomayos-Cameroon, 58.6\% and $50.2 \%$ of protein by Ngakou et al. (2012) but lower than $69.2 \%$ of protein obtained by Mbaïguinam et al. (2006). This could be attributed to the availability of essential elements (N and P) in Jourdan's medium as well as the tendency of algae for bioaccumulation and incorporation of these elements into their macromolecules. Furthermore this analysis revealed that total ash and some minerals $(\mathrm{Ca}, \mathrm{Mg}, \mathrm{K}, \mathrm{Fe}$ and $\mathrm{P}$ ) were much higher than those reported by Ngakou et al. (2012) and Ama Moor et al. (2016). These differences could be explained by either the influence of culture media, the difference in climate, or caused by the differentiated cellular metabolism in as much as these elements are actively involved in the metabolism of S. platensis. Reversely, lipids, fibers and sodium contents appeared to be lower. This could be due particularly for lipids content to a variation of the extraction method or the type of solvent used (Ama Moor et al., 2016). Thus the strain of $S$. platensis used in this experiment contains macronutrients and essential micronutrients absorbed from its growth medium become chelated with amino acids and are therefore more easily assimilated by the body and is considered as an excellent food supplement, nephrotoxicity effect of pharmaceuticals and toxic metals, immunological properties and acts as a potent antioxidant.

Considering, magnesium sulphate $\left(\mathrm{MgSO}_{4}\right)$, the concentration $0.16 \mathrm{~g} / \mathrm{L}$ gave higher content of protein. Protein contents were increased with $\mathrm{K}_{2} \mathrm{SO}_{4}$ content in culture media (the highest protein contents were obtained with $1.28 \mathrm{~g} / \mathrm{L}$ ). The combination of both salt generated the highest protein content with $0.02 / 0.14 \mathrm{~g} / \mathrm{L} \mathrm{MgSO} \mathrm{Mg}_{2} / \mathrm{KO}_{4}$. These results highlight the benefit effect of sulphate salts nutrition on proteins accumulation in S. platensis biomass. However, this benefit effect depends on sulphate salt type and $\mathrm{Mg}^{2+} / \mathrm{K}^{+}$ratio. S. platensis seems to not tolerate high concentration of $\mathrm{Mg}^{2+}$. This might indicate the toxicity of magnesium sulphate at highest concentration in S. platensis biomass (Wakte et al., 2011). Reversely, high $\mathrm{K}^{+}$promotes protein accumulation in S. platensis biomass.

Cysteine content analysis in S. platensis biomass (relation sulphate nutrition) revealed the influence of sulphate salt type and $\mathrm{Mg}^{2+} / \mathrm{K}^{+}$ratio on content of this sulphurous amino acid (as with protein content). The accumulation of cysteine with increasing content of $\mathrm{K}_{2} \mathrm{SO}_{4}$ might indicate that, the availability of sulphate promote the assimilation of sulphur for the synthesis of cysteine (a sulphur-containing amino acid). However, this promoting effect appeared to be stimulate by high content of $\mathrm{K}^{+}$in culture media; but altered by high content of $\mathrm{Mg}^{2+}$ (above $0.16 \mathrm{~g} / \mathrm{L}$ ) in culture media. The increase in $\mathrm{SO}_{4}{ }^{2-}$ concentration caused an increase in cysteine due to essential role of sulphur in synthesis of amino acids like cysteine which make up proteins and enters in the composition of chlorophyll and has a direct implication in the enzymatic catalysis (Schwenk, 2012).

Reducing sugars contents in S. platensis biomass displayed a reverse pattern compared to protein and cysteine contents. This might reveal that, the sulphate supply in culture media leads the use of reducing sugars for synthesis of cysteine which is utilized for protein building. Negative and significant correlation was found between cysteine contents, protein contents and reducing sugars.

These changes in biochemical composition could be correlated with the essential role played by the ions $\mathrm{K}^{+}$and $\mathrm{Mg}^{2+}$ in the assimilation of sulphur and the growth of S. platensis (Dea Prianka et al., 2019).

Algae are negatively affected by harmful reactive oxygen species (ROS) produced by photosynthetic electron transport, photorespiration, respiration and other metabolic processes which may cause the deterioration of cell metabolism and damage cellular components (Foyer et al., 2011; Mostafa Mahmoud et al., 2016). To alleviate the harmful effects of ROS, S. platensis have developed several mechanisms such as antioxidants enzymes in which the polyphenol oxidase (PPO) and peroxidase (POD) play a significant role. The enhanced activity of PPO and $\mathrm{POD}$ in $S$. platensis biomass in lower $\mathrm{MgSO}_{4}$ and higher $\mathrm{K}_{2} \mathrm{SO}_{4}$ concentrations observed in the present study may suggest a cooperative role of these antioxidants enzymes in protection of $S$. platensis cells against ROS. 
Highest PPO and POD activities matched with highest protein, cysteine contents and biomass production. These set of results might reveal that an adequate sulphate supply leads to optimal biomass production, protein and cysteine accumulation under appropriate PPO and POD activities which preserved spirulina cells against ROS (Mostafa Mahmoud et al., 2016; Panahi et al., 2019).

\section{Conclusion}

Medium composition is one of the key factors that control S. platensis growth, biochemical status and antioxidant activity. From the present study, it could be concluded that high yield of biomass (number of filaments, biomass concentration, cell productivity and specific growth rate), biochemical status (protein, cysteine and reducing sugars) and antioxidant enzymes activities (PPO and POD) were sulphate salt type and concentration dependent. $S$. platensis cultured in medium supplemented with both $\mathrm{MgSO}_{4}$ and $\mathrm{K}_{2} \mathrm{SO}_{4}$ was characterized by highest growth performance, biochemical status (protein, cysteine and reducing sugars) and antioxidant activities (PPO and POD). These sets of results draw attention to the importance of selecting the source and concentration of sulphate salts for $S$. platensis culture. Sulphate nutrition appeared to be useful to improve growth performance and biochemical status (nutritional value and antioxidant activity) of this cyanobacterium which is important in further explored for their use for medicinal products and additives in pharmaceutical, food, cosmetic or other industrial applications.

\section{Acknowledgements}

The authors would also like to thank the SAGRIC Common Initiative Group (CIG) farm, Douala-Cameroon who graciously provided us with the Spirulina Strain.

\section{References}

Abdel-Daim, M. M., Abuzead, S. M. M., Halawa, S. M., \& Partha, M. (2013). Protective Role of Spirulina platensis against Acute Deltamethrin-Induced Toxicity in Rats. Public Library of Science, 8, 1371-1371. https://doi.org/10.1371/journal.pone.0072991

Al-Saman, M. A., Doleib, N. M., Ibrahim, M. R., Nasr, M. Y., Tayel, A. A., \& Hamouda, R. A. (2020). In vitro and in vivo hypolipidemic properties of the aqueous extract of Spirulina platensis, cultivated in colored flasks under artificial illumination. PeerJ, 8, e10366 https://doi.org/10.7717/peerj.10366

Ama Moor, V. J., Pieme, C. A., Nkeck J. R., Nya Biapa, C. P., Ikomey, M. G., Kouanfack, C., ... Ngogang, J. (2020). Spirulina platensis enhances immune status, inflammatory and oxidative markers of HIV patients on antiretroviral therapy in Cameroon. Research Square, 1602-6494. https://doi.org/10.21203/rs.2.22360/v1

Ama Moor, V. J., Pieme, C. A., Nya Biapa, C. P., Ngo-Matip, M. E., Moukette, B. M., Tankeu, F. N., ... Ngogang, J. (2015). Chemical composition of Spirulina platensis of nomayos- Yaoundé (Cameroon). Annals. Food Science and Technology, 17, 524-528.

Anna, F. R. (2018). Correlation between conductivity and total dissolved solid in various type of water: A review. IOP Conference Series: Earth and Environmental Science, 118, 012019. https://doi.org/10.1088/1755-1315/ $118 / 1 / 012019$

AOAC (Association of Official Analytical Chemists). (1990). Official Methods of Analysis (15th ed.). Association of Official Analytical Chemists, Arlington, USA.

AOAC (Association of Official Analytical Chemists). (1995). Official Methods of Analysis (16th ed.). Association of Official Analytical Chemists, Arlington, USA.

Azabji-Kenfack, M., Loni, G. E., Sobngwi, E., Onana, E. A., Edie, D. S., \& Von Der Weid, D. (2011). The Effect of Spirulina platensis versus Soybean on Insulin Resistance in HIV-Infected Patients: A Randomized Pilot Study. Nutrients, 3, 712-724. https://doi.org/10.3390/nu3070712

Barakat, W., Shimaa, M., \& Mahmoud, A. (2015). Spirulina platensis Lacks Antitumor Effect against Solid Ehrlich Carcinoma in Female Mice. Advances in Pharmacological Sciences, 2015, Article ID 132873. https://doi.org/10.1155/2015/132873

Ben Amor, F., Barkallah, M., Elleuch, F., Karkouch, N., Dammak, M., Baréa, B., ... Fendri, I. (2017). Cyanobacteria as source of marine bioactive compounds: Molecular specific detection based on D9 desaturase gene. International Journal of Biological Macromoles, 105, 1440-1445. https://doi.org/10.1016/ j.ijbiomac.2017.07.139

Bradford, M. (1976). A rapid and sensitive method for the quantitative of microgram quantities of protein utilizing the principle of protein-Dye binding. Analytical Biochemistry, 72, 248-254. https://doi.org/ 


\section{$10.1016 / 0003-2697(76) 90527-3$}

Budiyono, Syaichurrozi, I., Sumardiono, S., \& Budi Sasongko, S. (2014). Production of Spirulina platensis biomass using digested vinasse as cultivation medium. Trends in Applied Sciences Research, 9, 93-102. https://doi.org/10.3923/tasr.2014.93.102

Carfagna, S., Salbitani, G., Bottone, C., De Marco, A., \& Vona, V. (2015). Cross-effects of nitrogen and sulphur starvation in Chlorella sorokiniana 211/8K. Natural Resources, 6, 221-229. https://doi.org/10.4236/ nr.2015.64020

Çelekli, A., Topyürek, A., Markou G., \& Bozkurt, H. (2016). A Multivariate approach to evaluate biomass production, biochemical composition and stress compounds of Spirulina platensis cultivated in wastewater. Applied Biochemistry and Biotechnology, 2, 2122-2128.

Dea Prianka, A. I., \& Taufik, T. (2019). Biomass and Phycocyanin Production from Spirulina platensis cultivated in Anaerobically Digested Dairy Manure Waste $(A D D M W)$ with Sodium Bicarbonate Addition. Joint Symposium Plant Sciences and Product, Sith Itb \& UKM Malaysia.

Fatemeh, M., \& Choopani, A. (2020). Spirulina, food of past, present and future. Health Biotechnology and Biopharma, 3(4), 1-20.

Foyer, H., \& Shigeoka, S. (2011). Understanding oxidative stress and antioxidant functions to enhance photosynthesis1. Plant Physiology, 155, 93-100. https://doi.org/10.1104/pp.110.166181

Gaitonde, M. (1967). A Spectrophotometric method for the direct determination of cysteine in the presence of other naturally occurring amino acids. Biochemistry Journal, 104, 627-633. https://doi.org/10.1042/ bj1040627

Gómez-Téllez, A., Sierra-Puente, D., Muñoz-Gómez, R., Ibarra-Pitts, A., Guevara-Cruz, M., Hernández-Ortega, M., \& Gutiérrez-Salmeán, G. (2020). Effects of a Low-Dose Spirulina/Turmeric Supplement on Cardiometabolic and Antioxidant Serum Markers of Patients with Abdominal Obesity. Frontiers in Nutrition, 7, 65. https://doi.org/10.3389/fnut.2020.00065

Jourdan, J. P. (2013). Cultivez votre Spiruline. Manuel de culture artisanale pour la production de spiruline. Antenna Technologies (Consulté le 24/08/2018, p. 143). Retrieved from http://www.spirulinasource.com/ microjourdan.html

Jung, F., Kruger-Gengeb, A., Waldeck, P., \& Kupper, J.-H. (2019). Spirulina platensis, a super food? Journal of Cellular Biotechnology, 5, 43-54. https://doi.org/10.3233/JCB-189012

Kaushik, R., Prasanna, R., \& Joshi, C. (2006). Utilization of anaerobically digested distillery effluent for the production of Spirulina platensis (ARM 730). Journal of Scientific and Industrial Research, 65, 521-525.

Leustek, T. (2002). Sulphate Metabolism. The Arabidopsis Book 1: e0017 (p. 17). American Society of Plant Biologists. https://doi.org/10.1199/tab.0017

Liu, G., \& Wang, J. (2012). Effects of nano-copper (ii) oxide and nano-magnesium oxide particles on activated sludge. Water Environment Research, 84, 569-576. https://doi.org/10.2175/106143012X13373575830593

Luo, J., \& Jiang, L. (2015). Production of aquatic feed grade algal powder from turtle breeding wastewater using a locally isolated Spirulina sp. JXSC-S1. African Journal of Microbiology Research, 9, 2404-2409. https://doi.org/10.5897/AJMR2015.7602

Madkour, F., Abd El-Wahab, K., \& Hodam, S. (2012). Production and nutritive value of Spirulina platensis in reduced cost media. Egyptian Journal of Aquaculture Research, 38, 51-57. https://doi.org/10.1016/ j.ejar.2012.09.003

Mbaïguinam, M., Tarkodjiel, M., \& Maoura, N. (2006). Culture and comparison study of the chemical composition of blue algae of Kanem-Lake (Spirulina platensis). Applied Sciences and Health, 1, 10-21.

Mohan, I. K., Khan, M., Shobha, J. C., Naidu, M. U., Prayag, A., Kuppusamy, P., \& Kutala, V. K. (2006). Protection against cisplatin-induced nephrotoxicity by Spirulina in rats. Cancer Chemotherapy and Pharmacology, 58, 802-808. https://doi.org/10.1007/s00280-006-0231-8

Mostafa, M. S., Yassin E. M., \& Michele, P. N. (2016). Role of pH on antioxidants production by Spirulina (Arthrospira) platensis. Brasilian Journal of Microbiology, 47, 298-304. https://doi.org/10.1016/j.bjm. 2016.01.003

Ndjouondo, G. P., Dibong, S. D., Wamba, F. O., \& Taffouo. V. D. (2017). Growth, Productivity and Some 
Physico-chemical Factors of Spirulina platensis Cultivation as Influenced by Nutrients Change. International Journal of Botany, 13, 67-74. https://doi.org/10.3923/ijb.2017.67.74

Ngakou, A., Wague, R., Mbaillao, M., \& Namba, F. (2012). Changes in the physico-chemical properties of Spirulina platensis from three production sites in Chad. Journal of Animal and Plant Sciences, 3, 1811-1822.

Ngo-Matip, M. E., Pieme, C. A., Azabji-Kenfack, M., Moukette, B. M., Korosky, E., Stefanini, P., .. Mbofung, C. (2015). Impact of daily supplementation of Spirulina platensis on the immune system of naïve HIV-1 patients in Cameroon: A 12-months single blind, randomized, multicenter trial. Nutrition Journal, 4, 15-58. https://doi.org/10.1186/s12937-015-0058-4

Nyabuto, D., Cao, K., Mariga, A., Kibue, G., He, M., \& Wang, C. (2015). Growth performance and biochemical analysis of the genus Spirulina under different physical and chemical environmental factors. African Journal of Agricultural Research, 10(36), 3614-3624. https://doi.org/10.5897/AJAR2015.10210

Panahi, Y., Khosroshahi, A. Y., Sahebkar, Y., \& Heidari, H. R. (2019). Impact of Cultivation Condition and Media Content on Chlorella vulgaris Composition. Advanced Pharmaceutical Bulletin, 182-194. https://doi.org/10.15171/apb.2019.022

Priyanka ,Y., Jyoti, S., \& Vishal, M. (2020). Biosorption-Cum-Bioaccumulation of Heavy Metals from Industrial Effluent by Brown Algae: Deep Insight. Microbial Genomics in Sustainable Agroecosystems, 978-981-13.

Schwenk, J. R. (2012). Effects of Magnesium Sulfate, Digestate and Other Inorganic Nutrients on the Phototrophic Growth of the Green Microalga Scenedesmus Dimorphus. ETD Archive (p. 353).

Shigekatsu, S., Haruyo, Y., \& Masanobu, K. (2019). The Draft Genome of a Hydrogen-producing Cyanobacterium, Arthrospira platensis NIES-46. Journal of Genomics, 7, 56-59. https://doi.org/10.7150/ jgen.38149

Soundarapandian, P., \& Vasanthi, B. (2008). Effects of chemical parameters on Spirulina platensis biomass production: Optimized method for phycocyanin extraction. . International Journal of Zoology Research, 4, 1-11. https://doi.org/10.3923/ijzr.2008.1.11

Thorpe, T. A., \& Gaspar, T. (1978). Changes in isoperoxydase during shoot formation in tobacco callus. In Vitro, 14, 552-539. https://doi.org/10.1007/BF02616094

Tsarahevitra, J., Charpy, L., \& Vicente, N. (2003). Culture de Spiruline en eau de mer à Toliara (Madagascar). Colloque d'Ecologie Microbienne, Carry Le Rouet.

Usharani, G., Saranraj, P., \& Kanchana, D. (2012). In vitro cultivation of Spirulina platensis using rice mill effluent. International Journal of Pharmaceutical and Biological Archives, 3, 1518-1523.

Van Kammen, A., \& Broumer, D. (1964). Increase of polyphenol oxidase activity by the local virus infection in uninoculated parts of leaves. Virology, 22, 9-14. https://doi.org/10.1016/0042-6822(64)90042-X

Wagih, E.-S., Sharaf, M., Abd, A. E.-F., \& Abo-Eleneen, M. (2015). Production enhancement of some valuable compounds of Arthrospira platensis. Journal of Basic and Environmental Sciences, 2, 74-83.

Wakte, P., Mohite, Y., \& Bhusare, D. (2011). Influence of metal ions on growth and c-phycocyanin production in Arthrospira (Spirulina) platensis. Recent Research Science and Technology, 3, 104-108.

Wolff, J. P. (1968). Analytical Manual of fatty acids. Azoulay (p. 519). Paris, France.

Yakelín, R., Pérez, E., Solórzano, E., Meneses, A., \& Fernández, F. (2001). Peroxidase and polyphenol oxidase activities in tomato roots inoculated with Glomus clarum or Glomus fasciculatum. Cultivos Tropicales (pp. 11-16).

\section{Copyrights}

Copyright for this article is retained by the author(s), with first publication rights granted to the journal.

This is an open-access article distributed under the terms and conditions of the Creative Commons Attribution license (http://creativecommons.org/licenses/by/4.0/). 